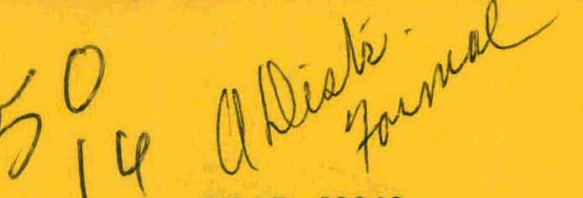

GEAP-10062

AEC RESEARCH AND

DEVELOPMENT REPORT

JUNE 1969

\title{
MECHANICAL PROPERTIES OF IRRADIATED TYPE-304 AND TYPE-316 STANILES STEEL IN FAST REACTORS
}

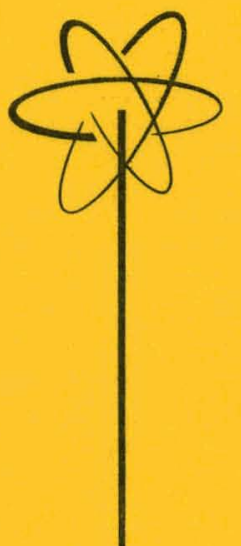

THIS DOCUMENT CONFIRMED AS DIVISION OF CLASSIFICATION BY DATE
F.A. COMPRELLI

H.J. BUSBOOM M.F. GEBHARDT

U.S. ATOMIC ENERGY COMMISSION CONTRACT AT(04-3)-189 PROJECT AGREEMENT 10

BREEDER REACTOR DEVELOPMENT OPERATION 


\section{DISCLAIMER}

This report was prepared as an account of work sponsored by an agency of the United States Government. Neither the United States Government nor any agency Thereof, nor any of their employees, makes any warranty, express or implied, or assumes any legal liability or responsibility for the accuracy, completeness, or usefulness of any information, apparatus, product, or process disclosed, or represents that its use would not infringe privately owned rights. Reference herein to any specific commercial product, process, or service by trade name, trademark, manufacturer, or otherwise does not necessarily constitute or imply its endorsement, recommendation, or favoring by the United States Government or any agency thereof. The views and opinions of authors expressed herein do not necessarily state or reflect those of the United States Government or any agency thereof. 


\section{DISCLAIMER}

Portions of this document may be illegible in electronic image products. Images are produced from the best available original document. 


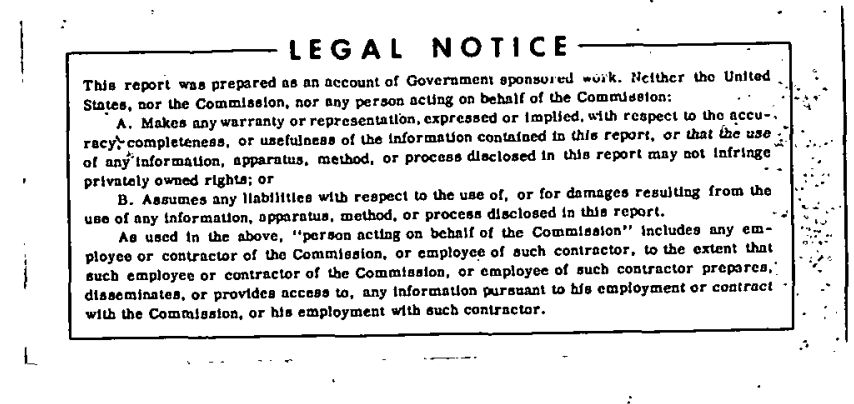

AEC Research and Development Report June 1969

\section{MECHANICAL PROPERTIES OF IRRADIATED TYPE-304 AND TYPE-316 STAINLESS STEEL IN FAST REACTORS}

by

F. A. Comprelli

H. J. Busboom

M. F. Gebhardt

Approved:

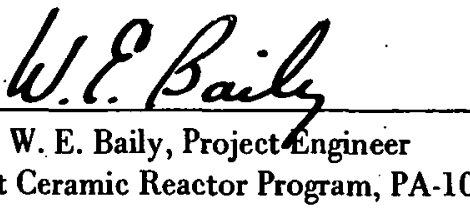

Approved:

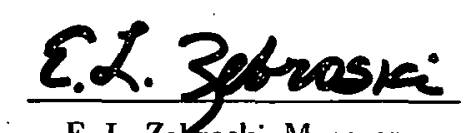

E. L. Zebroski, Manager Sodium Reactor Technology

Prepared for the

U. S. Atomic Energy Commission

Uñder Contract Number AT(04-3)-189

Project Agreement Number 10

Printed in U.S.A. Available from the

Clearing House for Federal Scientific and Technical Information

National Bureau of Standards, U.S. Department of Commerce

Springfield, Virginia

Price: $\$ 3.00$ per copy

\section{BREEDER REACTOR DEVELOPMENT OPERATION \\ GENERAL ELECTRIC \\ SUNNYVALE, CALIFORNIA}




\section{LEGAL NOTICE}

This report was prepared as an account of Government sponsored work. Neitber the United States, nor the Commission, nor any person acting on bebalf of the Commission:

A. Makes any warranty or representation, expressed or implied, wisb respect to tbe accuracy, completeness, or usefulness of the information contained in tbis report, or that tbe use of any information, apparatus, method, or process disclosed in this report may not infringe privately owned rights; or

B. Assumes any liabilities witb respect to tbe use of, or for damages resulting from the use of any information, apparatus, metbod, or process disclosed in this report.

As used in tbe above, "person acting on bebalf of tbe Commission" includes any employee or contractor of tbe Commission, or employee of sucb contractor, to the extent tbat sucb employee or contractor of the Commission, or employee of sucb contractor prepares, disseminates, or provides access to, any information pursuant to bis employment or contract with the Commission, or bis emplovment witb sucb contractor. 


\section{TABLE OF CONTENTS}

Summary ......................... 1

1. Introduction ....................... 1

2. Discussion of the Data . . . . . . . . . . . . . . . 1

2.1 Tensile Properties . . . . . . . . . . . . . . . 1

2.2 Burst Properties . . . . . . . . . . . . . . . . . 11

2.3 Creep Behavior . . . . . . . . . . . . . . . 11

3. Suggested Limits . . . . . . . . . . . . . . . . . 16

References ....................... 19 


\section{LIST OF ILLUSTRATIONS}

Figure

Title

Page

$1 \quad 0.2 \%$ Yield Stress Versus Test Temperature $\ldots \ldots \ldots \ldots \ldots \ldots \ldots$

2. Ultimate Tensile Stress Versus Test Temperature $\ldots \ldots \ldots \ldots$

3 Uniform Elongation Versus Test Temperature . . . . . . . . . . . . . . 4

4 Total Elongation Versus Test Temperature $\ldots \ldots \ldots \ldots$

$5 \quad 0.2 \%$ Yield Stress Versus Total Fluence at $600^{\circ} \mathrm{C}$ and $700^{\circ} \mathrm{C} \ldots \ldots \ldots$

6 Ultimate Tensile Stress Versus Total Fluence at $600^{\circ} \mathrm{C}$ and $700^{\circ} \mathrm{C} \ldots \ldots$

7 Uniform Elongation Versus Total Fluence at $600^{\circ} \mathrm{C}$ and $700^{\circ} \mathrm{C} \ldots \ldots \ldots$

8 Total Elongation Versus Total Fluence at $600^{\circ} \mathrm{C}$ and $700^{\circ} \mathrm{C} \ldots \ldots \ldots$

9 Strain Rate Dependence of Tensile Properties for Type 304 and Type 316

at $1300^{\circ} \mathrm{F}$ After Irradiation to $3.4 \times 10^{22}$ nvt Total . . . . . . . . . . . . . 10

10 Tubing Burst Properties of 304 as a Function of Test Temperature

After Irradiation in EBR-II . . . . . . . . . . . . . . . . . . 12

11 Parametric Relationship Between Applied Stress and Temperature -

Compensated Minimum Creep Rate (Thermal Reactor Data) - Type 304 . . . . . . . . 13

12 Parametric Relationship Between Applied Stress and Temperature -

Compensated Time-to-Rupture (Thermal Reactor Data) - Type 304 . . . . . . . . . 13

13 Parametric Relationship Betwcen Applied Stress and Temperature -

Compensated Minimum Creep Rate for Fast Reactor Data . . . . . . . . . . . . . 14

14. Parametric Relationship Between Applied Stress and Temperature -

Compensated Time-to-Rupture for Fast Keactor Data . . . . . . . . . . . . 15

15 Recommended Tensile Properties Above Total Fluences of $10^{22}$ nvt as

A Function of Test Temperature - Type-304 and -316 Stainless Steel . . . . . . . . 17

16 :Recommended Tensile Properties as a Function of Total Fluence at

$600^{\circ} \mathrm{C}$ and $700^{\circ} \mathrm{C}$ - Type-304 and Type 416 Stainless Steel $\ldots \ldots \ldots 17$

17 :Parametric Design Curves for Minimum Creep Rate and Time-to-Rupture in

Fast Reactor Environment at Fluences Ahove. $10^{22}$ nvt Type-304

and Type-316 Stainless Steel . . . . . . . . . . . . . . . 18 


\section{SUMMARY}

All data published to November 1968 on the mechanical properties of irradiated Type-304 and Type-316 stainless steel have been compiled and analyzed, and property limits are suggested for current use by designers. Revision of these limits in the light of new data is to be expected.

For use at total fluences above $10^{22} \mathrm{nvt}$, the following property limits are suggested:

- Yield stress at $0.2 \%$ offset: 44,000 psi at $500^{\circ} \mathrm{C}$ 31,000 psi at $600^{\circ} \mathrm{C}$ $\ddot{2} 0,000$ psi at $700^{\circ} \mathrm{C}$

- Ultimate stress:

58,000 psi at $500^{\circ} \mathrm{C}$

$46,000 \mathrm{psi}$ at $600^{\circ} \mathrm{C}$

30,000 psi at $700^{\circ} \mathrm{C}$

- Uniform elongation: less than $1 \%$

- Total elongation: less than $1 \%$

- Minimum creep rate: unchanged to slightly increased by irradiation

- Time to rupture: reduced significantly by irradiation

- Creep strain to fracture: as low as $\mathrm{i} \%$

\section{INTRODUCTION}

Loss in ductility of stainless alloys at high temperature as a result of neutron irradiation was recognized as a major problem since 1962 and a major effort was initiated to evaluate the performance limits. Neutron exposures which correspond to projected economic fuel burnups in fast reactors have been estimated about $3 \times 10^{23}$ nvt. Thus far, the highest exposure achieved is $8 \times 10^{22}$ nvt $(\geqslant 1.0$ $\mathrm{MeV}$ ). The major portion of published data was gathered in experiments conducted in Dounreay Fast Reactor (DFR) and EBR-II. Very little effort has been made prior to this study to collect the results obtained and relate the residual mechanical properties of irradiated steels to fuel element designs.

The information reviewed in this study represents the published efforts of General Electric-BRDO, Pacific Northwest Laboratory, Oak Ridge National Laboratory, Argonne
National Laboratory, General Electric-NSP, UKAEACulchetch, Harwell, and Dounreay, and the Centre d'Entudes Nucleaires deSaclay, France. As such, the data were gathered under a broad range of irradiation conditions and post-irradiation test parameters. The interpretation of the data was focused on the design needs at the operating conditions of an LMFBR (Liquid Metal Fast Breeder Reactor). Where applicable, uncertainties in existing data are noted.

This report deals with the analysis of information which has been published, judgment of the metallurgical trends, and the suggestions of performance limits for the materials of interest, Type-304 and Type-316 stainless steel for LMFBR's. These suggested limits should be reviewed and modified as new data are gathered and understanding of the phenomenon has progrcssed.

\section{DISCUSSION OF THE DATA}

The effect of irradiation upon mechanical properties of Type-304 and Type-316 stainless steel was considered from three viewpoints: tensile data, burst propcrties and creep-rupture behavior, and suggested limits for use by designers wcre made for each.

For the most part, only data at fluences greater than $10^{22}$ nvt have been considered. Because no data are available at fluences greater than $10^{23} \mathrm{nvt}$, extrapolation to the design conditions of LMFBR's must be considered tenuous. However, it is reasonable to assume that the minimum property levels, apparent at fluences less than $10^{23} \mathrm{nvt}$, will not be improved with continuing exposure.

\subsection{TENSILE PROPERTIES}

Available data (Ref. 1-8) are primarily from irradiations in EBR-II and DFR and all at either low temperatures during irradiation, relatively low fluence or both. The available data for Typc-304 and Type-316 stainless steel in the annealed condition are plotted in Figures 1 through 4.
These figures show the variation of yield stress, ultimate tensile stress, uniform elongation ${ }^{*}$ and total elongation $^{* *}$ as a function of test temperature. On these curves, the data are limited to Type-304 and Type-316 stainless steel which had been irradiated to total fluences ${ }^{* * *}$ greater than $10^{22}$ nvt at irradiation temperatures from $250^{\circ} \mathrm{C}$ $\left(482^{\circ} \mathrm{F}\right)$ to $670^{\circ} \mathrm{C}\left(1238^{\circ} \mathrm{F}\right)$. In Figures 5 through 8 , the primary tensile properties are plotted as a function of total fluence at test temperatures of $600^{\circ} \mathrm{C}\left(1112^{\circ} \mathrm{F}\right)$ and $700^{\circ} \mathrm{C}$ $\left(1292^{\circ} \mathrm{F}\right)$.

* Uniform elongation is defined as the strain to the onset of necking or plastic instability.

* Total elongation is defined as the strain at rupture.

*** All EBR-II total fluence values in this report are hased upon Argonne National Laboratory physics calculations (power normalization) reported in the EBR-II Operations Quarterly Reports. Current estimates indicate that these reported values should be corrected by $1 / 1.2$. This correction has not been made in the EBR-II data reported here. 


\begin{tabular}{|c|c|c|c|c|c|}
\hline SYMBOL & MATERIAL & $\begin{array}{c}\text { TOTAL } \\
\text { FLUENCE } \\
\left(\times 10^{22}\right)\end{array}$ & REFERENCE & $\begin{array}{c}\text { IRRADIATION } \\
\text { TEMPERATURE } \\
\left({ }^{\circ} \mathrm{C}\right)\end{array}$ & $\begin{array}{c}\text { STRAIN } \\
\text { RATE } \\
(\mathrm{min}-1)\end{array}$ \\
\hline$O$ & 304 & 2.0 & $(1)$ & 538 & 0.02 \\
$\otimes$ & 304 & 1.7 & $(2)$ & $590 \pm 80$ & 0.002 \\
$\otimes$ & 304 & 2.0 & $(3)$ & 380 & 0.02 \\
$\nabla$ & 304 & 3.4 & $(4)$ & $590 \pm 80$ & 0.02 \\
$\Delta$ & 316 & 3.6 & $(7)$ & $250-350$ & 0.095 \\
$\Delta$ & $316 L$ & 3.4 & $(4)$ & $590 \pm 80$ & 0.02 \\
\hline UIIID & 304 AND 316 UNIRRADIATED STANDARDS \\
\hline
\end{tabular}

TEST TEMPERATURE $\left({ }^{\circ} \mathrm{C}\right)$

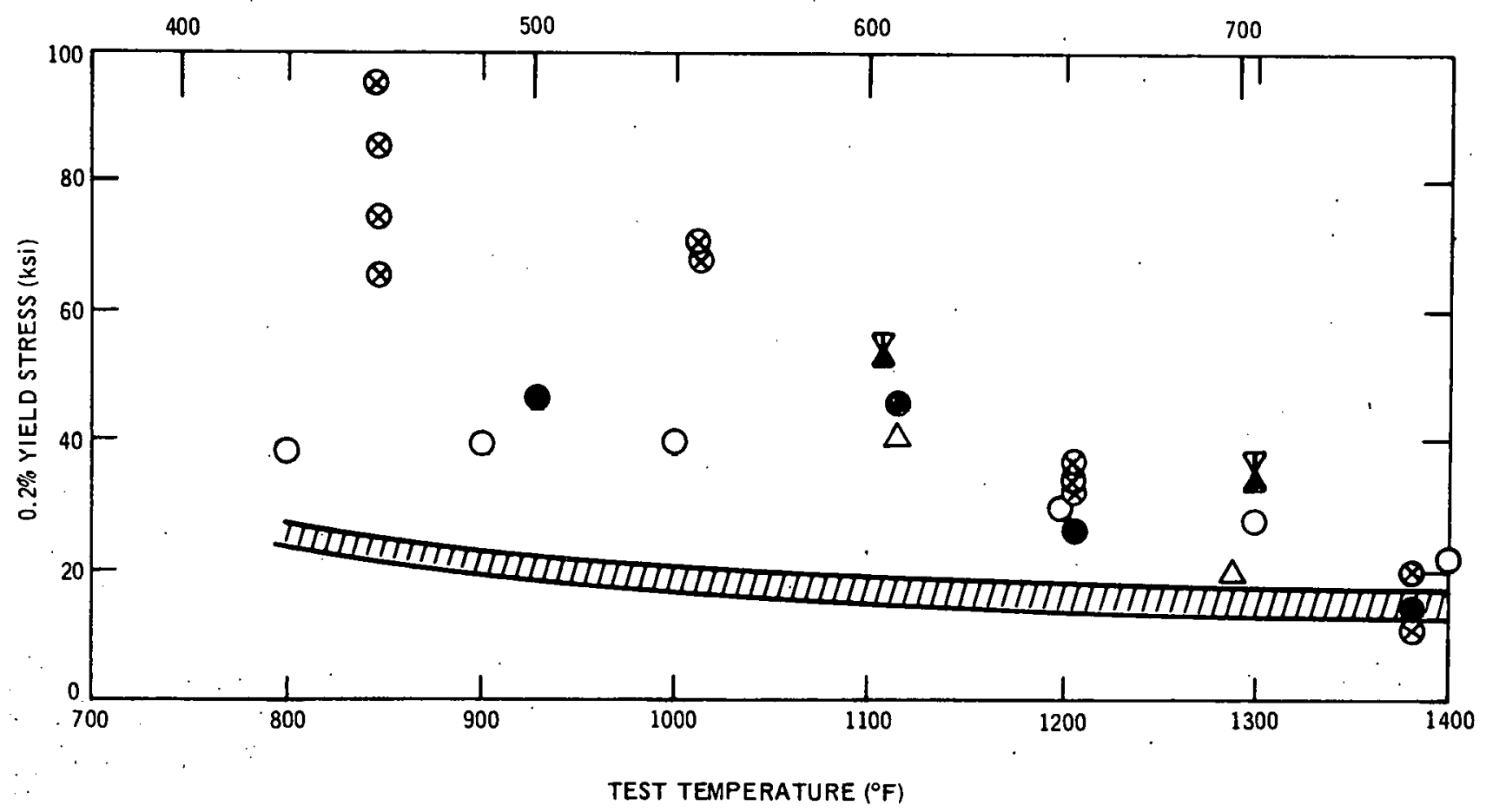

Figure 1. $0.2 \%$ Yield Stress Versus Test Temperature 


\begin{tabular}{|c|c|c|c|c|c|}
\hline SYMBOL & MATERIAL & $\begin{array}{l}\text { TOTAL } \\
\text { FLUENCE } \\
\left(\times 10^{22}\right)\end{array}$ & REFERENCE & $\begin{array}{l}\text { IRRADIATION } \\
\text { TEMPERATURE } \\
\left({ }^{\circ} \mathrm{C}\right)\end{array}$ & $\begin{array}{l}\text { STRAIN } \\
\text { RATE } \\
\left(\mathrm{min}^{-1}\right)\end{array}$ \\
\hline 0 & 304 & 2.0 & (1) & 538 & 0.02 \\
\hline & 304 & 1.7 & (2) & $590 \pm 80$ & 0.002 \\
\hline 8 & 304 & 2.0 & (3) & 380 & 0.02 \\
\hline$\nabla$ & 304 & 3.4 & (4) & $590 \pm 80$ & 0.02 \\
\hline$\triangle$ & 316 & 3.6 & (7) & $250-350$ & 0.095 \\
\hline$\Delta$ & 316L & 3.4 & (4) & $590 \pm 80$ & 0.02 \\
\hline EIIIID & \multicolumn{3}{|c|}{304 AND 316 UNIRRADIATED STANDARDS } & & \\
\hline
\end{tabular}

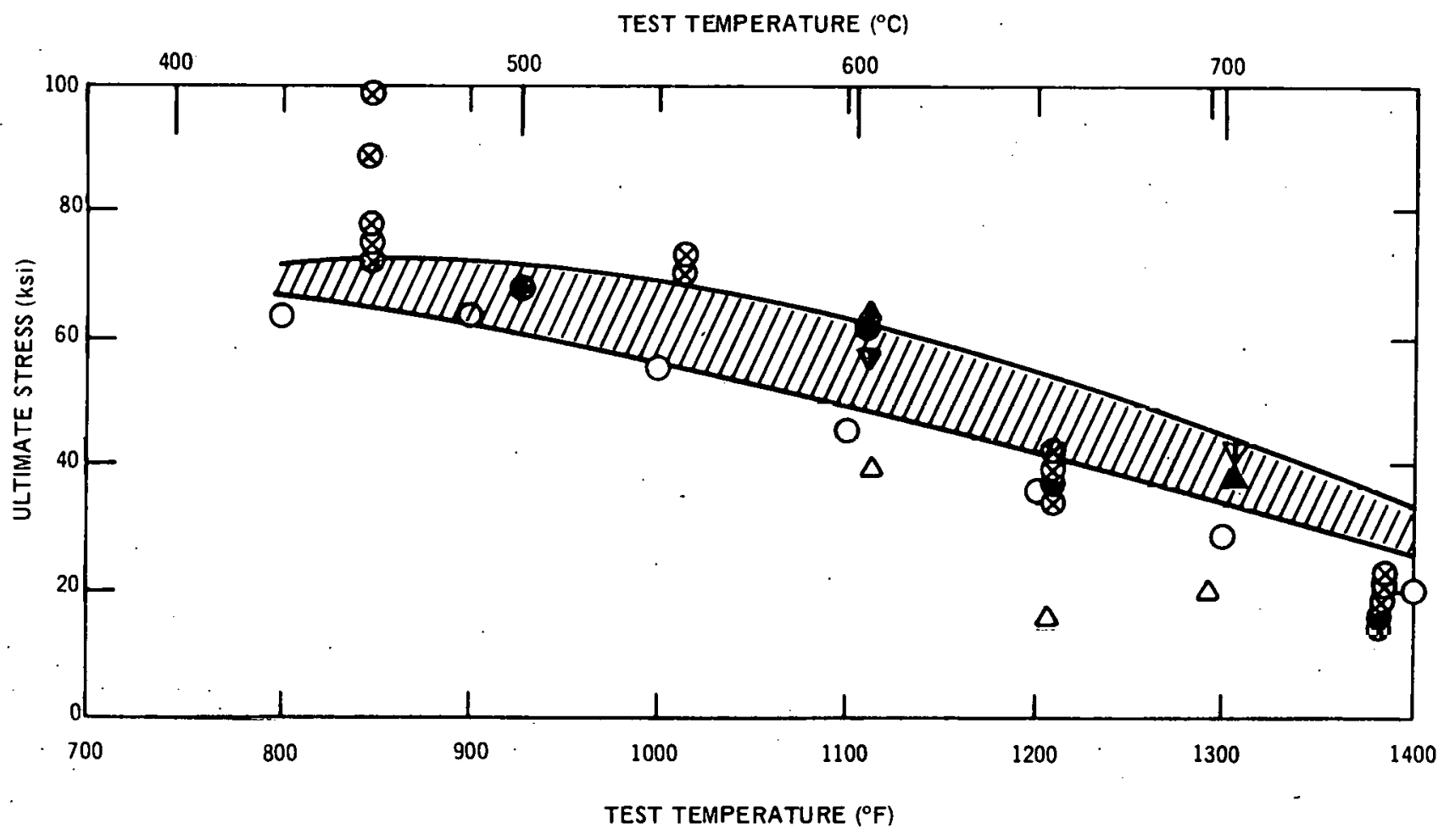

Figure 2. Ultimate Tensile Stress Versus Test Temperature 


\begin{tabular}{|c|c|c|c|c|c|}
\hline SYMBOL & MATERIAL & $\begin{array}{c}\text { TOTAL } \\
\text { FLUENCE } \\
(\times 1022)\end{array}$ & REFERENCE & $\begin{array}{c}\text { IRRADIATION } \\
\text { TEMPERATURE } \\
\left({ }^{\circ} \mathrm{C}\right)\end{array}$ & $\begin{array}{c}\text { STRAIN } \\
\text { RATE } \\
(\mathrm{min}-1)\end{array}$ \\
\hline 0 & 304 & 2.0 & $(1)$ & .538 & 0.02 \\
0 & 304 & 1.7 & $(2)$ & $590 \pm 80$ & 0.002 \\
$\boldsymbol{\nabla}$ & 304 & 2.0 & $(3)$ & 380 & 0.02 \\
$\nabla$ & 304 & 3.4 & $(4)$ & $590 \pm 80$ & 0.02 \\
$\Delta$ & 316 & 3.6 & $(7)$ & $250-350$ & 0.095 \\
$\Delta$ & $316 \mathrm{~L}$ & 3.4 & $(4)$ & $590 \pm 80$ & 0.02 \\
\hline
\end{tabular}

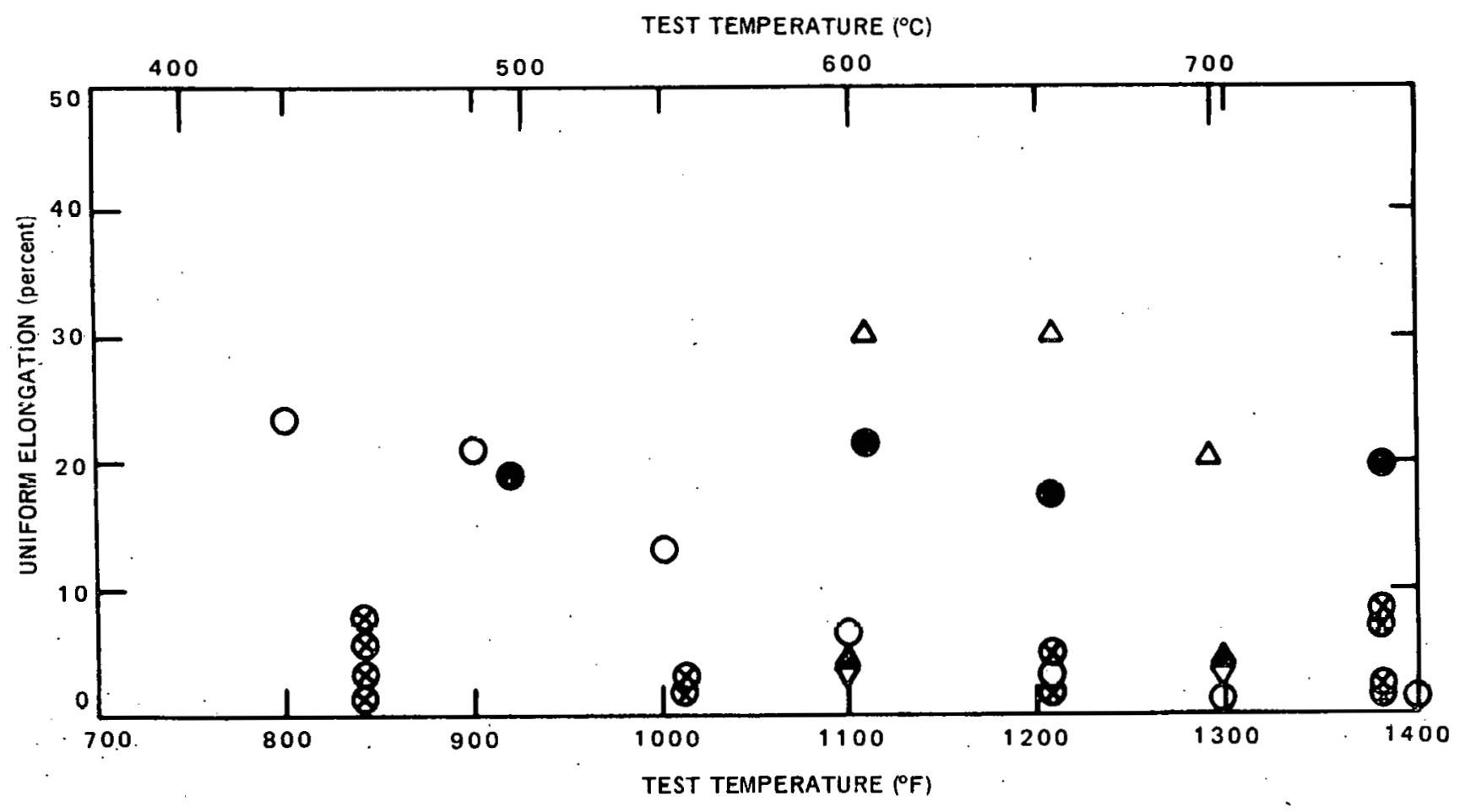

Figure 3. Uniform Elongation Versus Test Temperature 


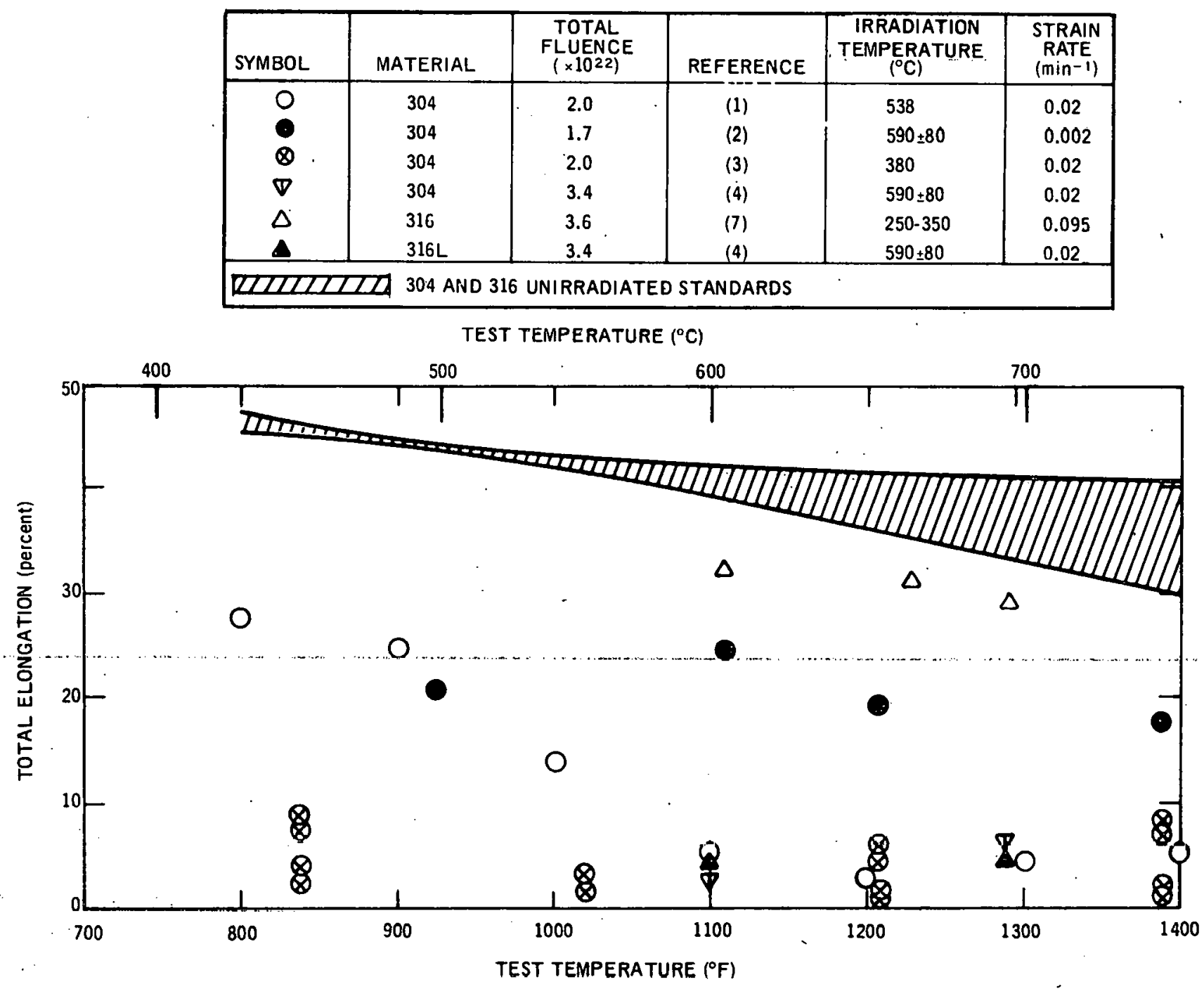

Figure 4. Total Elongation Versus Test Temperature 

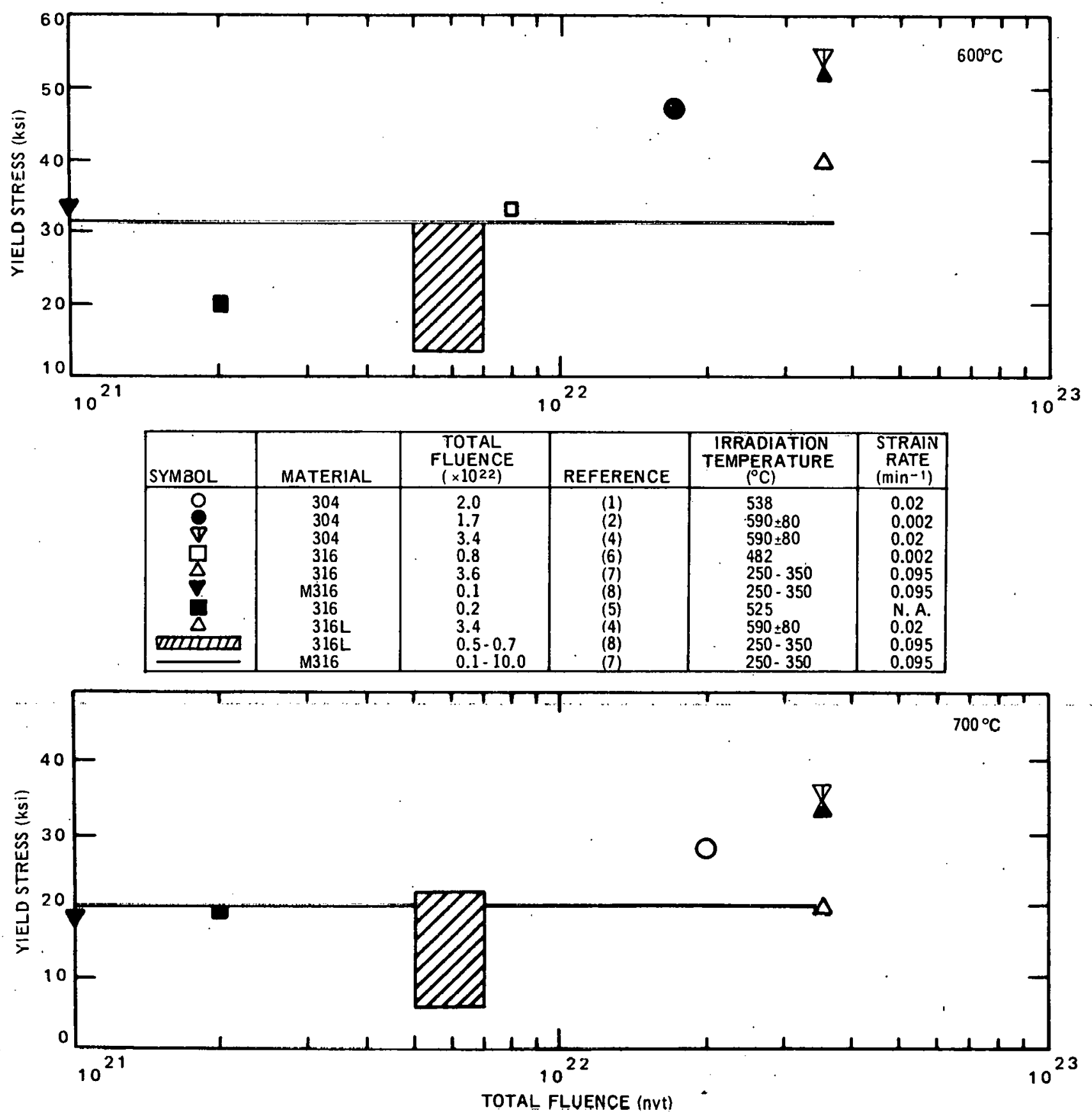

Figure 5. $\quad 0.2 \%$ Yield Stress Versus Total Fluence at $600^{\circ}$ and $700^{\circ} \mathrm{C}$ 

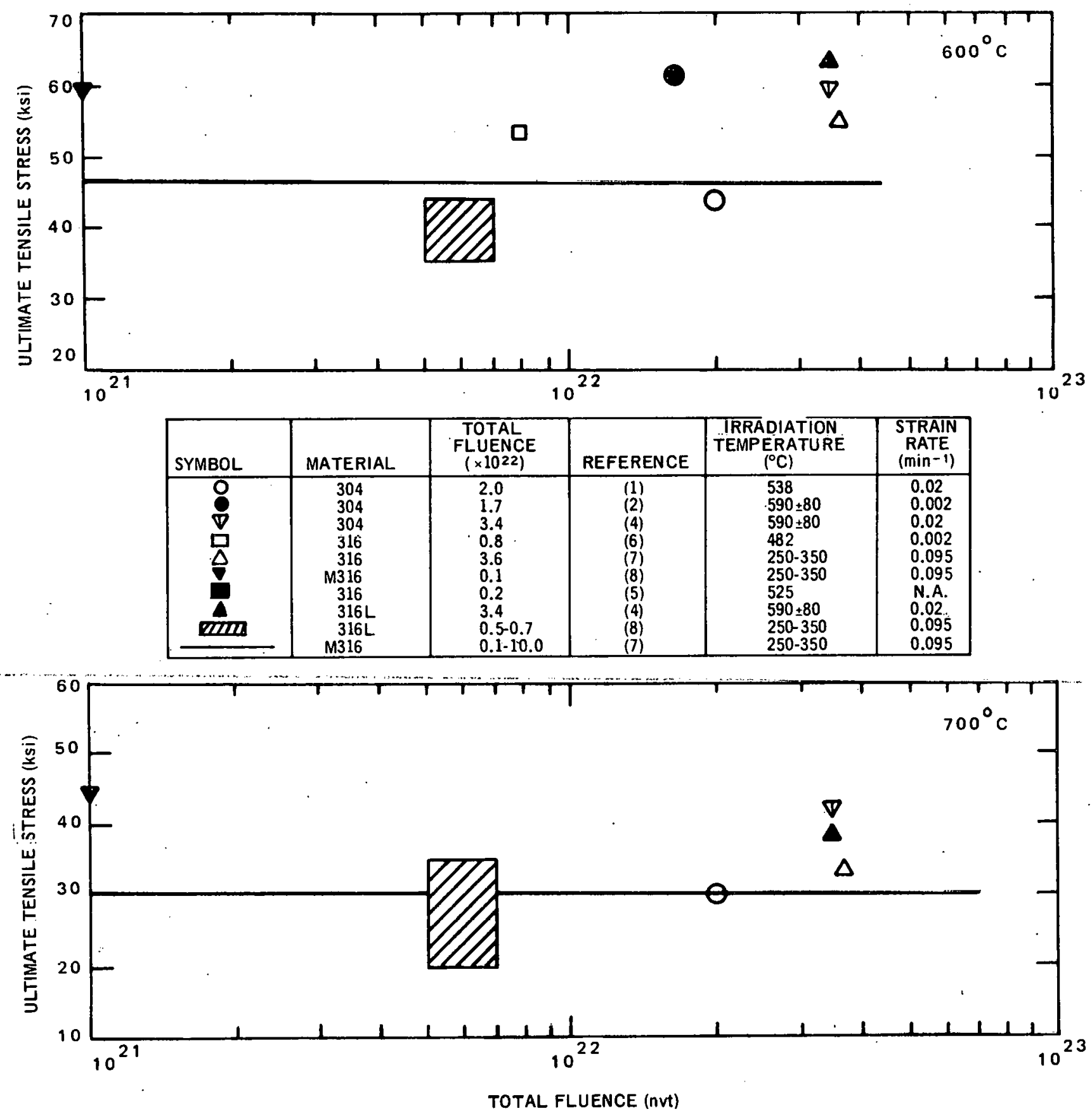

Figure 6. Ultimate Tensile Stress Versus Total Fluence at $600^{\circ}$ and $700^{\circ} \mathrm{C}$ 


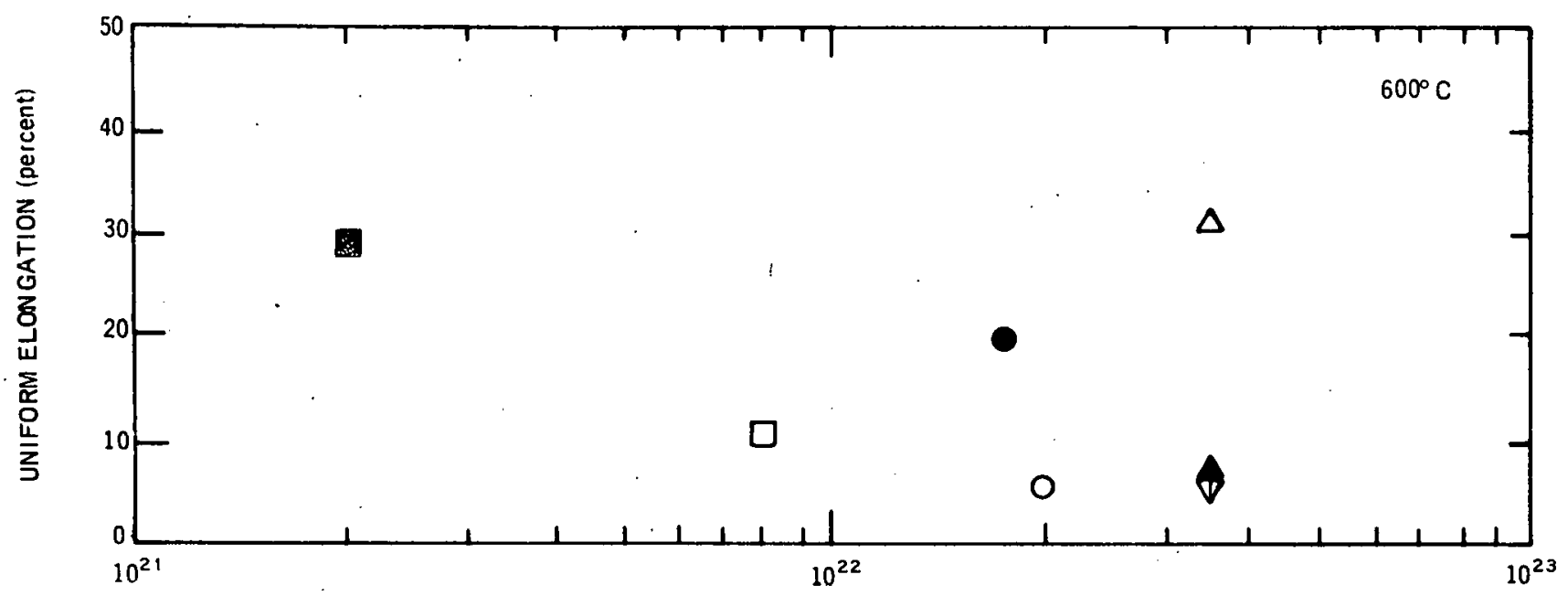

\begin{tabular}{|c|c|c|c|c|c|}
\hline SYMBOL & MATERIAL & $\begin{array}{l}\text { TOTAL } \\
\text { FLUENCE } \\
\left(\times 10^{22}\right)\end{array}$ & REFERENCE & \begin{tabular}{|c|} 
IRRADIATION \\
TEMPERATURE \\
$\left({ }^{\circ} \mathrm{C}\right)$
\end{tabular} & $\begin{array}{l}\text { STRAIN } \\
\text { RATE } \\
\left(\mathrm{min}^{-1)}\right.\end{array}$ \\
\hline $\begin{array}{l}8 \\
0 \\
0 \\
0\end{array}$ & $\begin{array}{l}304 \\
304 \\
304 \\
316 \\
316 \\
316 \\
316 \mathrm{~L}\end{array}$ & $\begin{array}{l}2.0 \\
1.7 \\
3.4 \\
0.8 \\
3.6 \\
0.2 \\
3.4\end{array}$ & $\begin{array}{l}(1) \\
(2) \\
(4) \\
(6) \\
(7) \\
(5) \\
(4)\end{array}$ & \begin{tabular}{|l|}
538 \\
$590 \pm 80$ \\
$590 \pm 80$ \\
482 \\
$250 \cdot-350$ \\
525 \\
$590 \pm 80$
\end{tabular} & $\begin{array}{l}0.02 \\
0.002 \\
0.02 \\
0.002 \\
0.095 \\
\text { N.A. } \\
0.02\end{array}$ \\
\hline
\end{tabular}

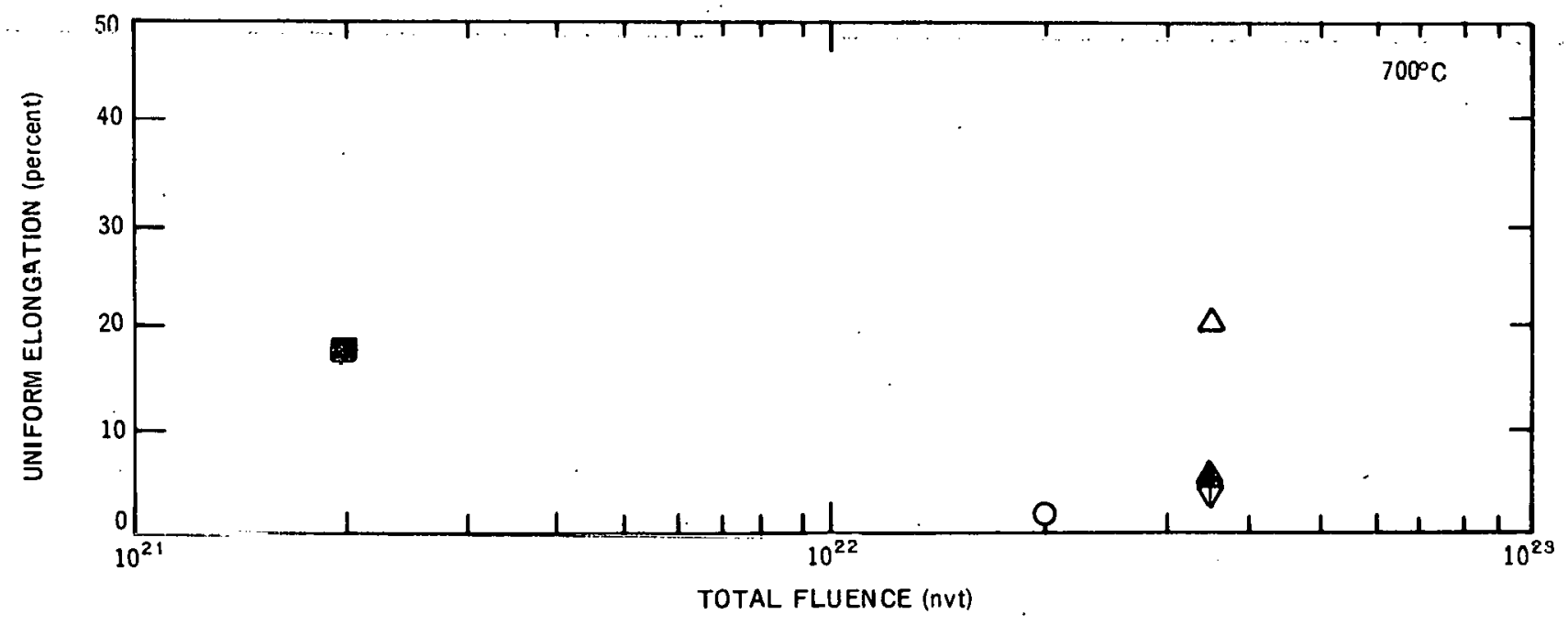

Figure 7. Uniform Elongation Versus Total Fluence at $600^{\circ}$ and $700^{\circ} \mathrm{C}$ 

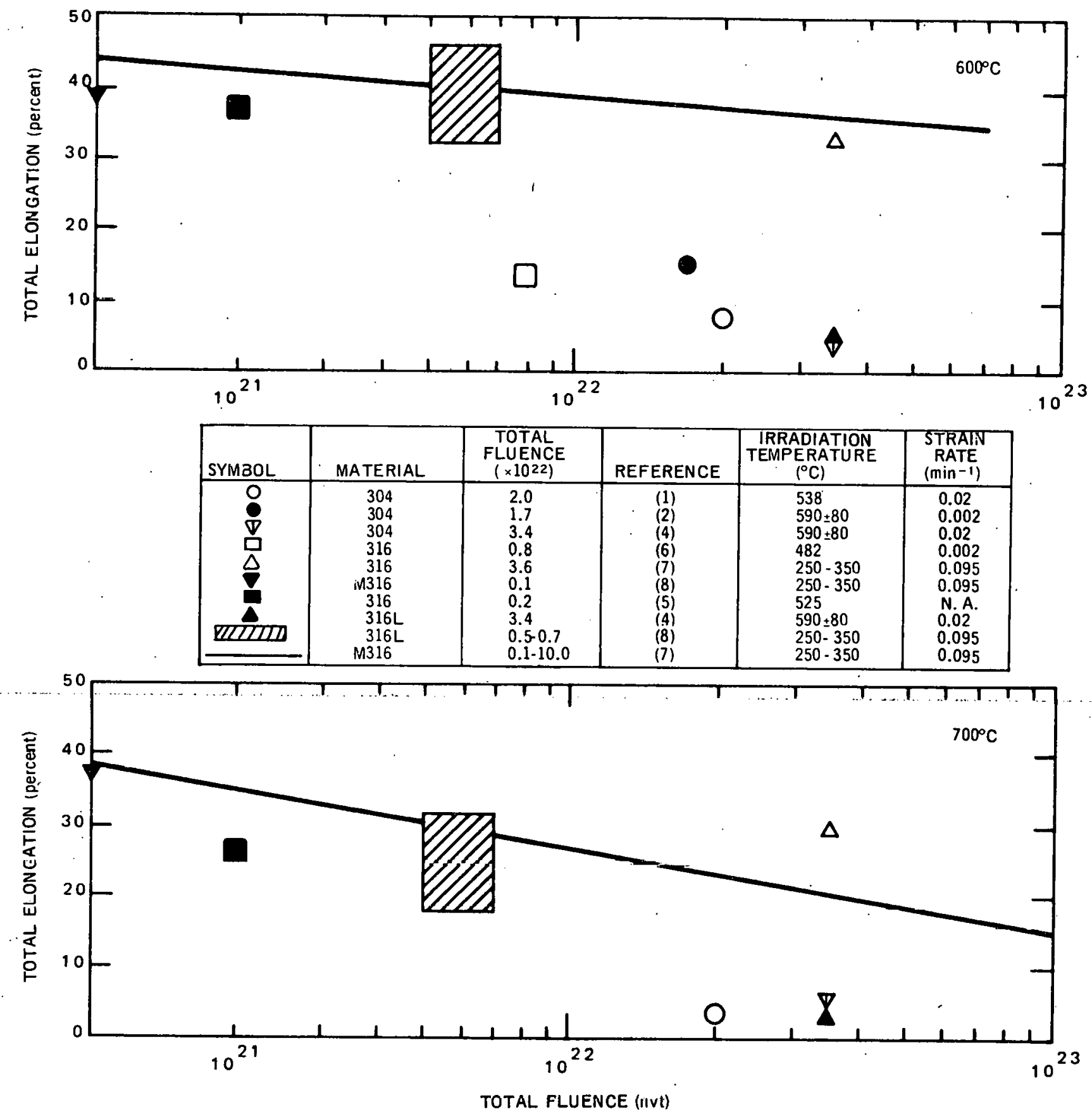

Figure 8. Total Elongation Versus Total Fluence at $600^{\circ} \mathrm{C}$ and $700^{\circ} \mathrm{C}$ 
These figures show that significant increases in yield strength can be expected at test temperatures up to $760^{\circ} \mathrm{C}$ $\left(1400^{\circ} \mathrm{F}\right)$ for all conditions of irradiation reported. However, this strengthening should not become an essential requirement for effective design. Ultimate tensile strengths were not found to increase in the same manner, and at the higher temperatures were lower than unirradiated values, which is a reflection of the sharp reduction in postirradiation elongation. The elongation data are widely scattered and reflect the sensitivity of this measurement both to irradiation conditions (temperature, fluence, and neutron spectrum) and post-irradiation test parameters (temperature and strain-rate). However, all elongations were reduced by irradiation. Elongation values of less than $10 \%$ werc common, with a considerable amount of the uniform elongation data falling below $2 \%$. A trend of decreasing elongation with increasing fluence is apparent.

The effect of strain rate on uniaxial tensile properties was also examined (Ref. 4) for Type-304 and Type-316 stainless steel. The results are shown in Figure 9 for tests at $1300^{\circ} \mathrm{F}$ after irradiation in EBR-II to $3.4 \times 10^{22}$ nvt total. At the slower strain rates, strength is appreciably reduced, probably associated with a change in deformation mechanisms. The total elongation does not seem to be significantly affected over the range investigated. However, extrapolation of this behavior to lower strain rates and biaxial loading patterns may be misleading as discussed in the later section on creep properties.

For comparative purposes, tensile data for coldworked material are listed in Table I. The PNL studies (Ref. 2) were on Type-304 stainless steel which had been coldrolled $25 \%$ and then irradiated to $1.7 \times 10^{22}$ nvt total in EBR-II at $590 \pm 80^{\circ} \mathrm{C}$. The UK data (Ref. 7) were generated on M316* which had been prestrained $17 \%$ (probably in tension) prior to irradiation in DFR at $250-350^{\circ} \mathrm{C}$ to $\sim 5 \times 10^{22}$ nvt total. The testing strain rates were $0.002 / \mathrm{min}$ for PNL and $0.095 / \mathrm{min}$ for the UK, which accounts for some of the difference in the data.

* M316 has the nominal composition: $0.04 \mathrm{C}, 1.0 \mathrm{Mn}, 0.2$ to $0.5 \mathrm{Si}$, 15.5-17 Cr, 14-15.5 Ni, 1.5-1.9 Mo, 0.002 B, 0.005 Al, 0.03V.

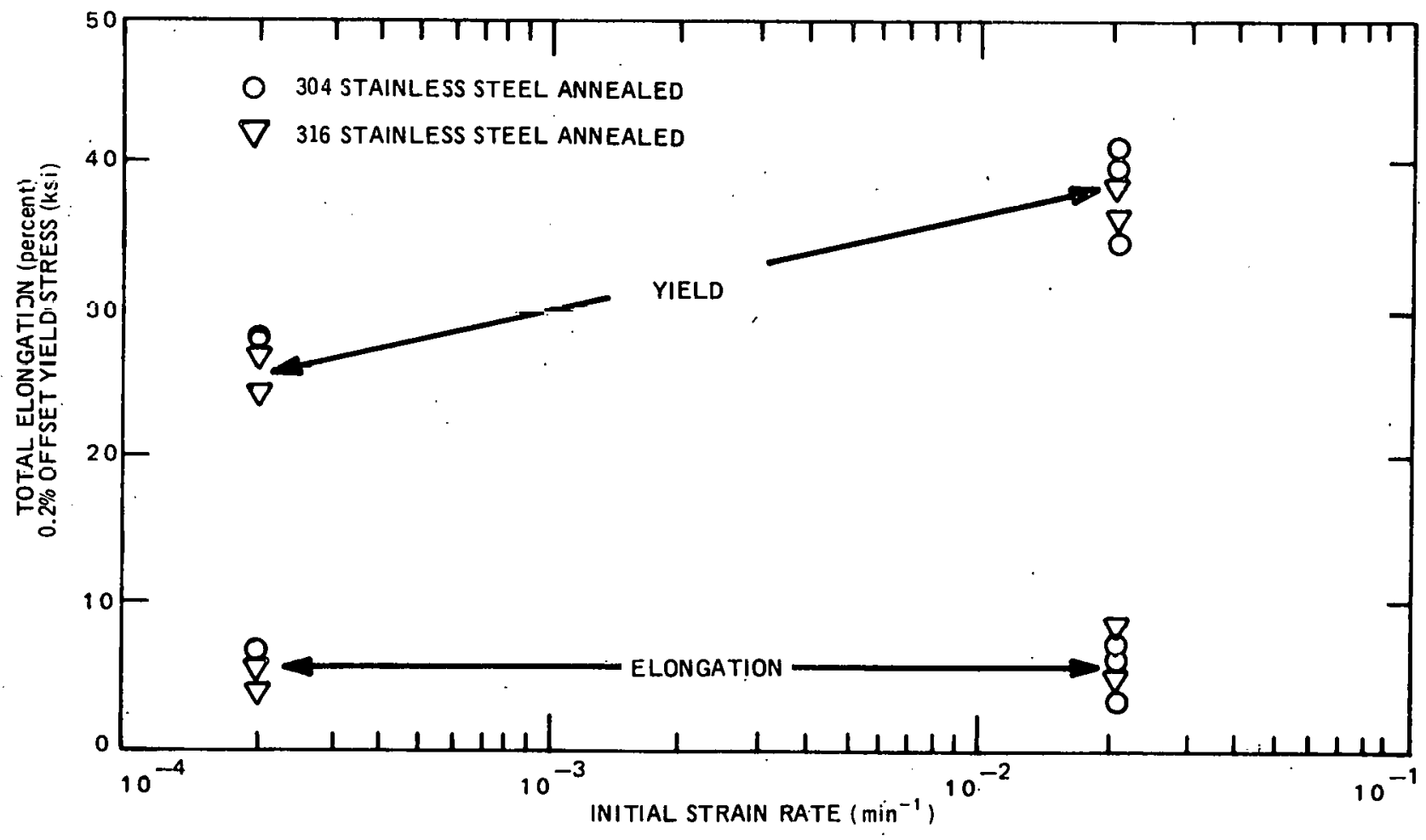

Figure 9. Strain Rate Dependence of Tensile Properties for Type-304 and Type--316 at $1300^{\circ} \mathrm{F}$ After Irradiation to $3.4 \times 10^{22}$ nvt Total 
Table 1

DATA. ON COLD.WORKED MATERIAL

PNL (Type 304)*

$\begin{array}{cccc}\begin{array}{c}\text { Test } \\ \text { Temperature } \\ {\left[{ }^{\circ} \mathrm{C}(\mathrm{F})\right]}\end{array} & \begin{array}{c}\mathbf{0 . 2 \%} \\ \text { Yield } \\ \text { Stress } \\ \text { (ksi) }\end{array} & \begin{array}{c}\text { Ultimate } \\ \text { Tensile } \\ \text { Strength } \\ \text { (ksi) }\end{array} & \begin{array}{c}\text { Uniform } \\ \text { Elongation } \\ (\%)\end{array} \\ 500(932) & 79.2 & 87.2 & 3.7 \\ 600(1112) & & & \\ 650(1202) & 54.9 & 62.3 & 1.7 \\ 700(1292) & & & \\ 750(1382) & 27.7 & 35.1 & 1.3\end{array}$

$\begin{gathered}\text { Total } \\ \text { Elongation } \\ (\%)\end{gathered}$
5.9
3.3
2.5

UK (Type M316)**

\begin{tabular}{ccc}
$\begin{array}{c}\text { 0.2\% } \\
\text { Yield }\end{array}$ & $\begin{array}{c}\text { Ultimate } \\
\text { Tensile } \\
\text { Strength } \\
\text { (ksi) }\end{array}$ & $\begin{array}{c}\text { Total } \\
\text { Elongation } \\
\text { (ks) }\end{array}$ \\
\hline 94 & 96 & \\
56 & 64 & 11 \\
44 & 54 & 19 \\
40 & 47 & 18 \\
& & 11
\end{tabular}

\subsection{BURST PROPERTIES}

The available data, shown in Figure 10, were gathered at ANL (Ref. 9) on Type-304L stainless steel driver fuel cladding from EBR-II, and at GE-BRDO (Ref. 10) on Type-304 capsule tubing used for fuel tests in EBR-II. Both tubes were unstressed during irradiation. During the postirradiation testing, typical rupture times were $\sim 2$ minutes for the ANL specimens to as high as 40 minutes for the GE specimens. This difference in pressurizing rate did not significantly affect the consistency of results.

As can be seen in Figure 10, irradiation in EBR-II to total_fluence_levels_as_low_as_0.5_to_2.5 $\times 10^{22}$ nvt does sig. nificantly affect the burst properties of Type-304 tubing. Although data are not available, similar behavior can be expected for Type-316 tubing. Significant increases in strength were observed for the irradiated material at temperatures below $1300^{\circ} \mathrm{F}$, with corresponding reductions in diametral fracture strain. At test temperatures above $800^{\circ} \mathrm{F}$, fracture strains of less than $2 \%$ were typical, as compared to unirradiated values of $10 \%$ to $20 \%$.

\subsection{CREEP BEHAVIOR}

There has been a fair amount of creep work done, both in-pile and post-irradiation, in conjunction with the behavior of Type-304 stainless steel in thermal reactors. (Ref. 11) The data from these studies are presented parametrically in Figures 11 and 12 . The general conclusions reached in these studies were: (1) little, if any, significant difference exists between the secondary or mini-

* PNL-Pacific Northwest Laboratories. Cold-rolled to 25\% reduction, then irradiated to $1.7 \times 10^{22}$ nvt total in EBR-II at $590 \pm 80^{\circ} \mathrm{C}$. Testing strain rate: $0.002 / \mathrm{min}$ in EBR-II.

** UK-United Kingdom. Prestrained 17\%, then irradiated to $5 X$ $10^{22}$ nvt total in DFR at $350^{\circ} \mathrm{C}$. Testing strain rate: $0.095 / \mathrm{min}$. mum creep rate of irradiated and unirradiated specimens, and (2) a significant effect of neutron irradiation is observed in the reduction of creep rupture life and, correspondingly, fracture ductility.

Comparable information for a fast reactor environment is limited and therefore, a sweeping analysis is not possible. However, the fast reactor data available for both Type-304 and Type-316 stainless steel can be evaluated against the trends previously established for irradiation of Type-304 stainless steel in thermal reactors.

The effect of fast reactor exposure on the minimum or secondary-creep-rate-is-shown-in-Figure-1-3.-(-Ref-1-2-14) Except for the highly-stressed specimens, all values have fallen within the trend band established by the thermal irradiation data. In general, fast neutron bombardment had no effect or caused minor perturbations from thermalirradiation data. There are deviations from this trend, such as the French data (Ref. 12) and the high-stress PNL data, (Ref. 13) which showed an increase in the secondary creep rate after irradiation. All of the irradiated data were determined from relatively short-lifetime tests, and therefore the extrapolation of these data to lower strain rates is tenuous as discussed later.

For comparative purposes, UK data (Ref. 14) on $20 \%$ cold-worked Type-316 stainless steel are included in Figure 13. In addition to being considerably stronger than the annealed material, the cold-worked alloy showed an increase in secondary creep rate after irradiation in DFR.

The effect of fast neutron bombardment on rupture life (Ref. 12-14) is shown in Figure 14. As can be seen, a reduction in rupture life was observed for all annealed and cold-worked specimens. Although all data for annealed material do not fall within the thermal irradiation trend band, a comparable and consistent trend is evident for the fast reactor data. 

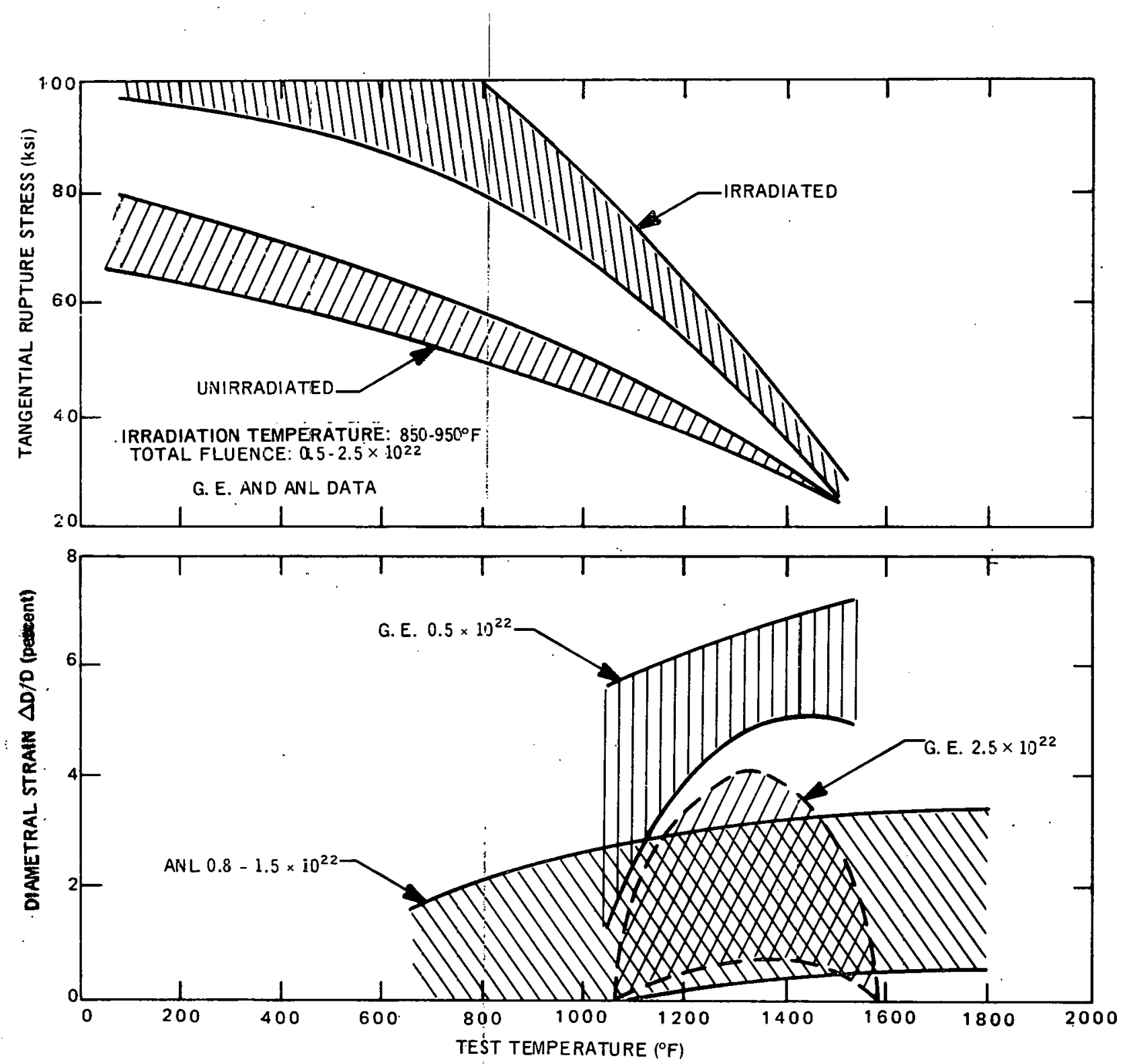


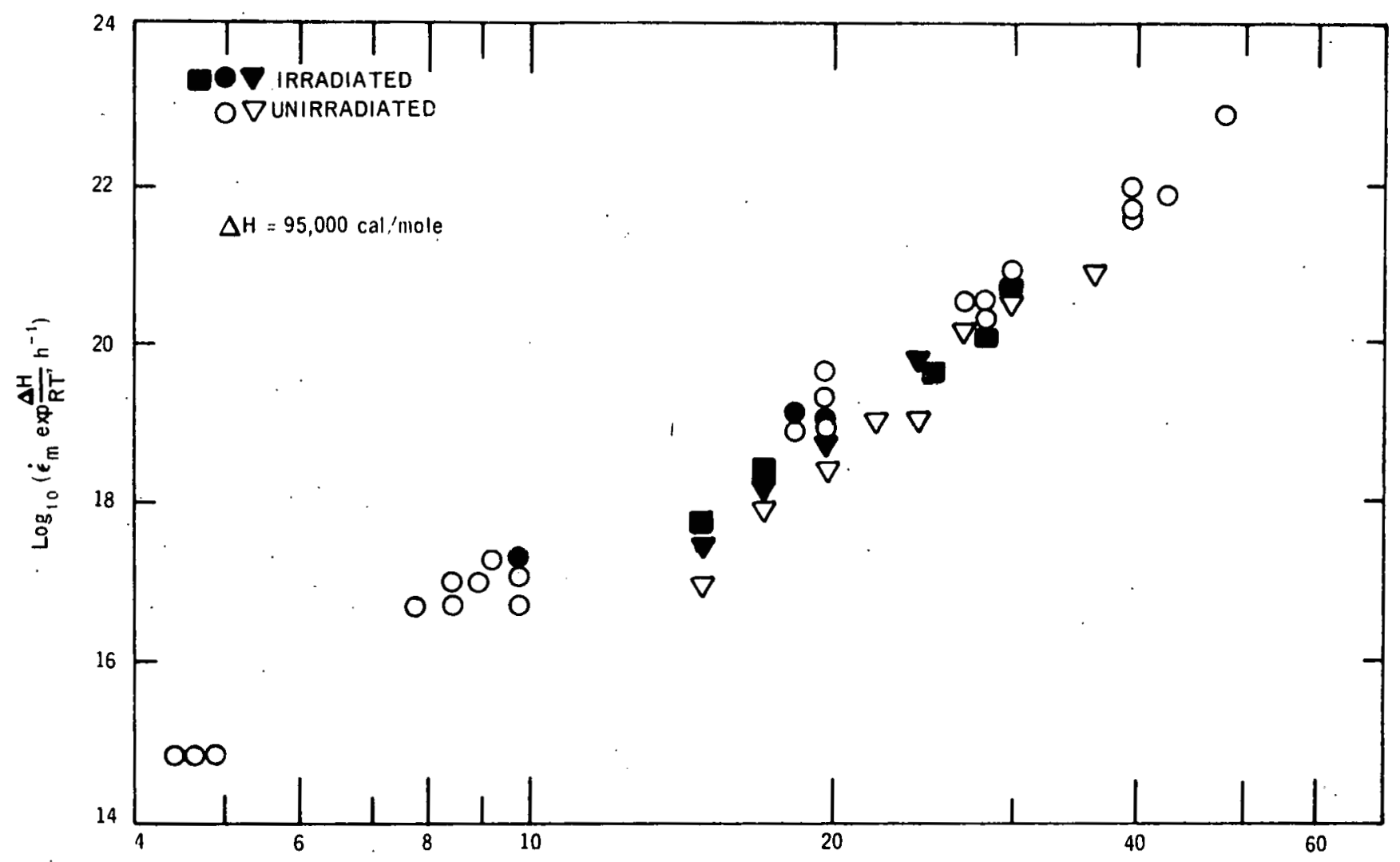

Figure 11. Parametric Relationship Between Applied Stress and Temperature Compensated Minimum Creep Rate (Thermal Reactor Data) - Type-304

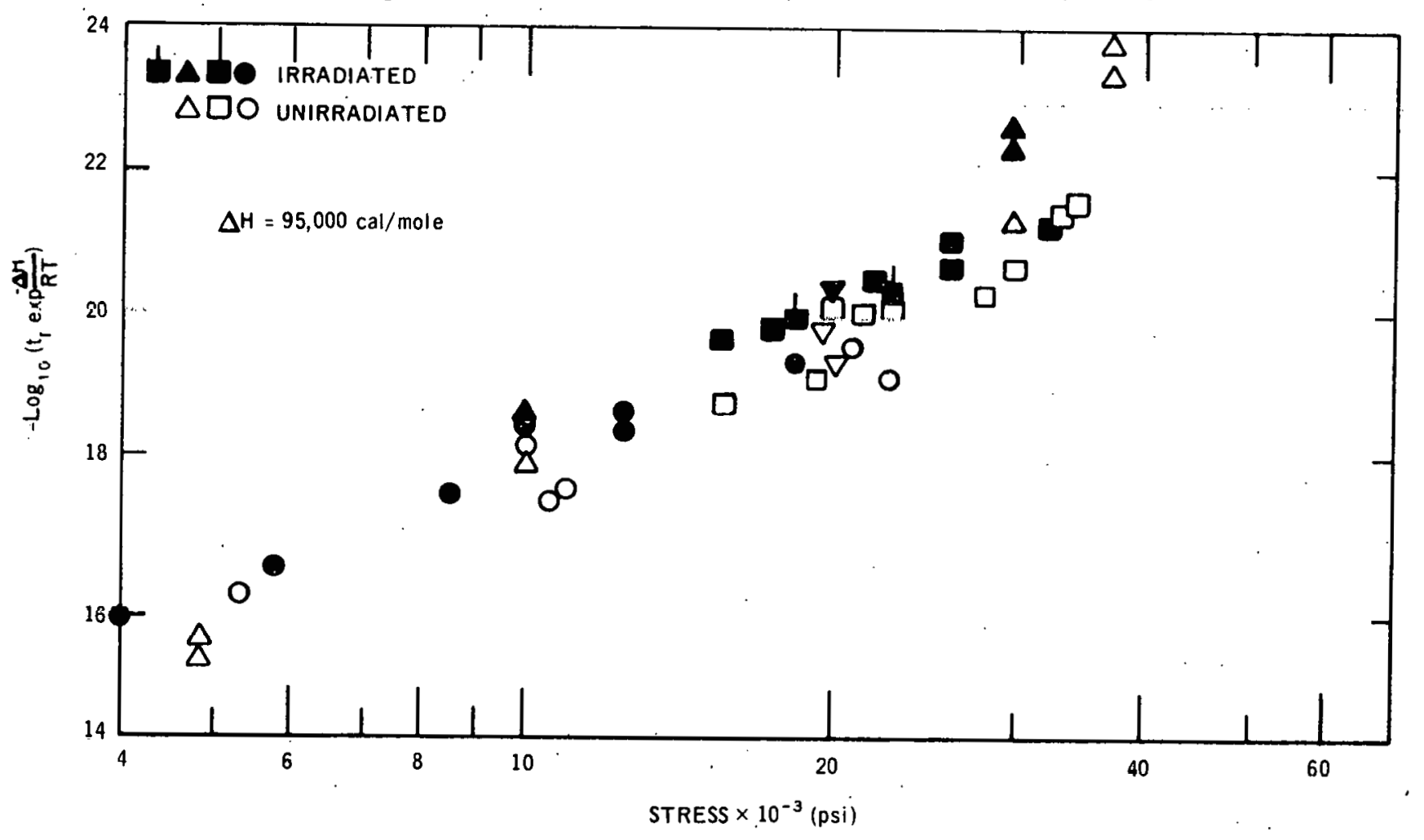

Figure 12. Parametric Relationship Between Applied Stress and Temperature Compensated Time-to-Rupture (Thermal Reactor Data) - Typo-304 


\begin{tabular}{|c|c|c|c|c|c|}
\hline \multicolumn{2}{|c|}{ SYMBOL } & \multirow[b]{2}{*}{ MATERIAL } & \multirow{2}{*}{$\begin{array}{c}\text { TOTAL } \\
\text { FLUENCE } \\
\left(\times 10^{22}\right) \\
\end{array}$} & \multirow{2}{*}{$\begin{array}{c}\text { TEST } \\
\text { TEMPERATURE } \\
\left({ }^{\circ} \mathrm{C}\right)\end{array}$} & \multirow[b]{2}{*}{ REFERENCE } \\
\hline IRRADIATED & UNIRRADIATED & & & & \\
\hline NOTE: C. W. & $\begin{array}{c}\text { No Data } \\
\text { No Data } \\
\sigma \\
0 \\
\text { Cold Worked } \\
\end{array}$ & $\begin{array}{l}316 \\
316 \\
316 \text { C.w. } \\
304 \\
316\end{array}$ & $\begin{array}{c}1.0-2.2 \\
0.4-1.6 \\
3.0 \\
1.4 \\
1.6\end{array}$ & $\begin{array}{c}650 \\
650 \\
650 \\
677-760 \\
700\end{array}$ & $\begin{array}{l}(14) \\
(14) \\
(14) \\
(13) \\
(12)\end{array}$ \\
\hline
\end{tabular}

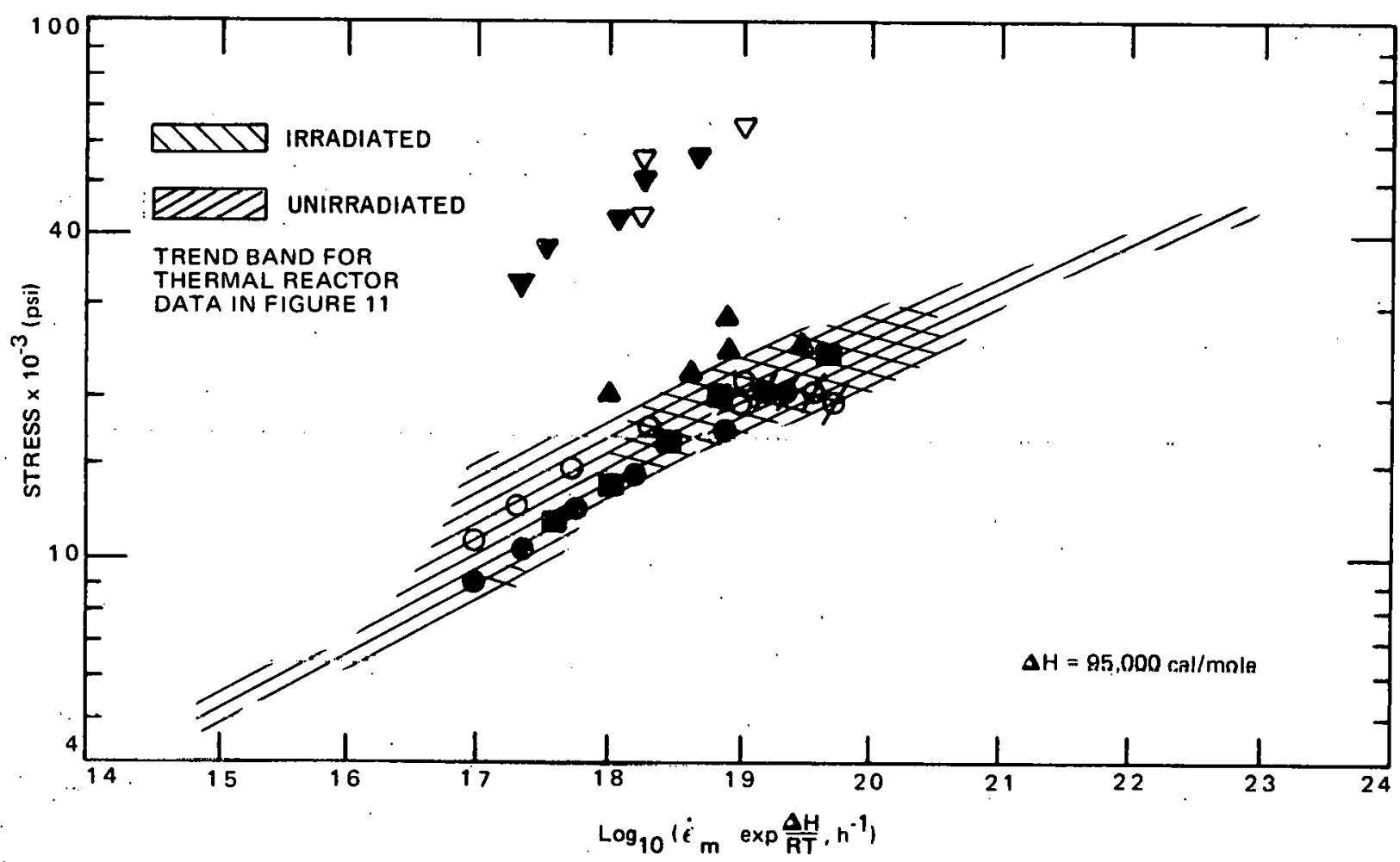

Figure 13. Parametric Relationship Between Applied Stress and Temperature -

Compensated Minimum Creep Rate for Fast Reactor Data 


\begin{tabular}{|c|c|c|c|c|c|}
\hline \multicolumn{2}{|c|}{ SYMBOL } & \multirow[b]{2}{*}{ MATERIAL } & \multirow{2}{*}{$\begin{array}{l}\text { TOTAL } \\
\text { FLUENCE } \\
\left(\times 10^{22}\right)\end{array}$} & \multirow{2}{*}{$\begin{array}{c}\text { TEST } \\
\text { TEMPERATURE } \\
\left({ }^{\circ} \mathrm{C}\right)\end{array}$} & \multirow[b]{2}{*}{ REFERENCE } \\
\hline IRRADIATED & UNIRRADIATED & & & & \\
\hline$\Delta$ & $\Delta$ & 316 & $1.0-2.2$ & 650 & (14) \\
\hline & & 316 & $0.4-1.6$ & 650 & (14) \\
\hline & & 316 C.W. & 3.0 & 650 & (14) \\
\hline & & 304 & 1.4 & $677-760$ & (13) \\
\hline & No Data & $316 \quad$, & 1.6 & 700 & (12) \\
\hline NOTE: C. W. & Cold Worked & & & & \\
\hline
\end{tabular}

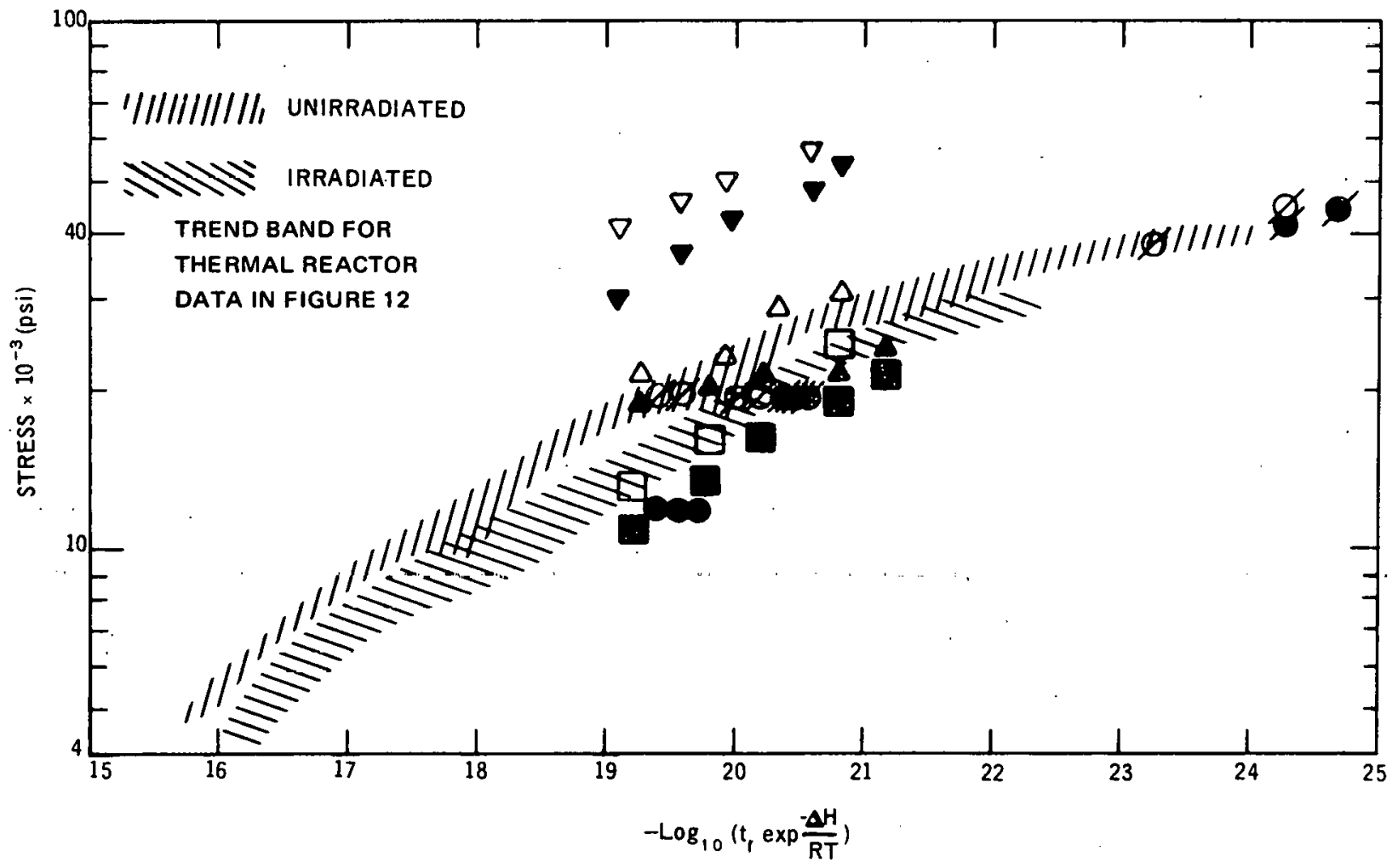

Figure 14. Parametric Relationship Between Applied Stress and Temperature Compensated Time-to-Rupture for Fast Reactor Data 
Data on rupture strain for tests at low strain rates are also uncommon for materials irradiated in fast reactors. Uniaxial tests for annealed Type-304 (Ref. 13) and Type-316 (Ref. 12) both showed rupture strains of $6 \%$. to $10 \%$ and higher at $1250^{\circ}$ to $1400^{\circ} \mathrm{F}$ after irradiation to $1.5 \times 10^{22}$ nvt total. However, biaxial tests on annealed tubing irradiated in DFR showed significantly lower rupture strains at $1200^{\circ} \mathrm{F}\left(650^{\circ} \mathrm{C}\right)$. Type-316L tubing dropped from unirradiated values of $5 \%$ to $17 \%$ and $2 \%$ to $5 \%$ after $1.35 \times 10^{22}$ nvt (Ref. 15) and leveled off at $2 \%$ after $3.5 \times$ $10^{22}$ nvt (Ref. 16). Type-316 tubing (Ref. 14) has shown reductions from $11 \%$ to $3 \%$ after 0.4 to $1.6 \times 10^{22}$ nvt and from $6 \%$ to $1 \%$ or $2 \%$ after 1 to $2.2 \times 10^{22}$ nvt. The rupture strains of the $20 \%$ cold-worked Type- 316 tubing ranged from $0.9 \%$ to $2.5 \%$ at $550^{\circ} \mathrm{C}\left(1022^{\circ} \mathrm{F}\right)$ after $3 \times 10^{22} \mathrm{nvt}$, which were comparable to unirradiated data for this material. These observations are consistent with a similar analysis (Ref. 17) made on annealed Type-304 and Type-316 stainless steel irradiated in thermal reactors, in which rupture strains predicted from uniaxial tests were an order of magnitude greater than extrapolations based on biaxial data ( $9 \%$ to $12 \%$ versus $0.8 \%$ to $1.2 \%$ ).

On the basis of these observations, it seems advisable that a strain limit of $1 \%$ be established for very low strainrate conditions.

\section{SUGGESTED LIMITS}

On the basis of these data, reasonable limits can be suggested for first round design analysis. The values in Figures 15 and 16 represent the probable minimum tensile properties for annealed Type-304 and Type-316 stainless steel which can be expected after irradiation in a fast reactor environment as a function of test temperature and - total fluence. The effect of temperature during irradiation could not be clearly ascertained from the pattern of data, but there are indications that lower irradiation temperatures are associated with greater increases in strength.

Parametric design curves for minimum creep rate and rupture lifetime are suggested in Figure 17 for Type-304 and Type-316 stainless steel after irradiation to total fluences greater than $10^{22}$ nvt. These curves represent the minimum level of performance as indicated by data published to date. 


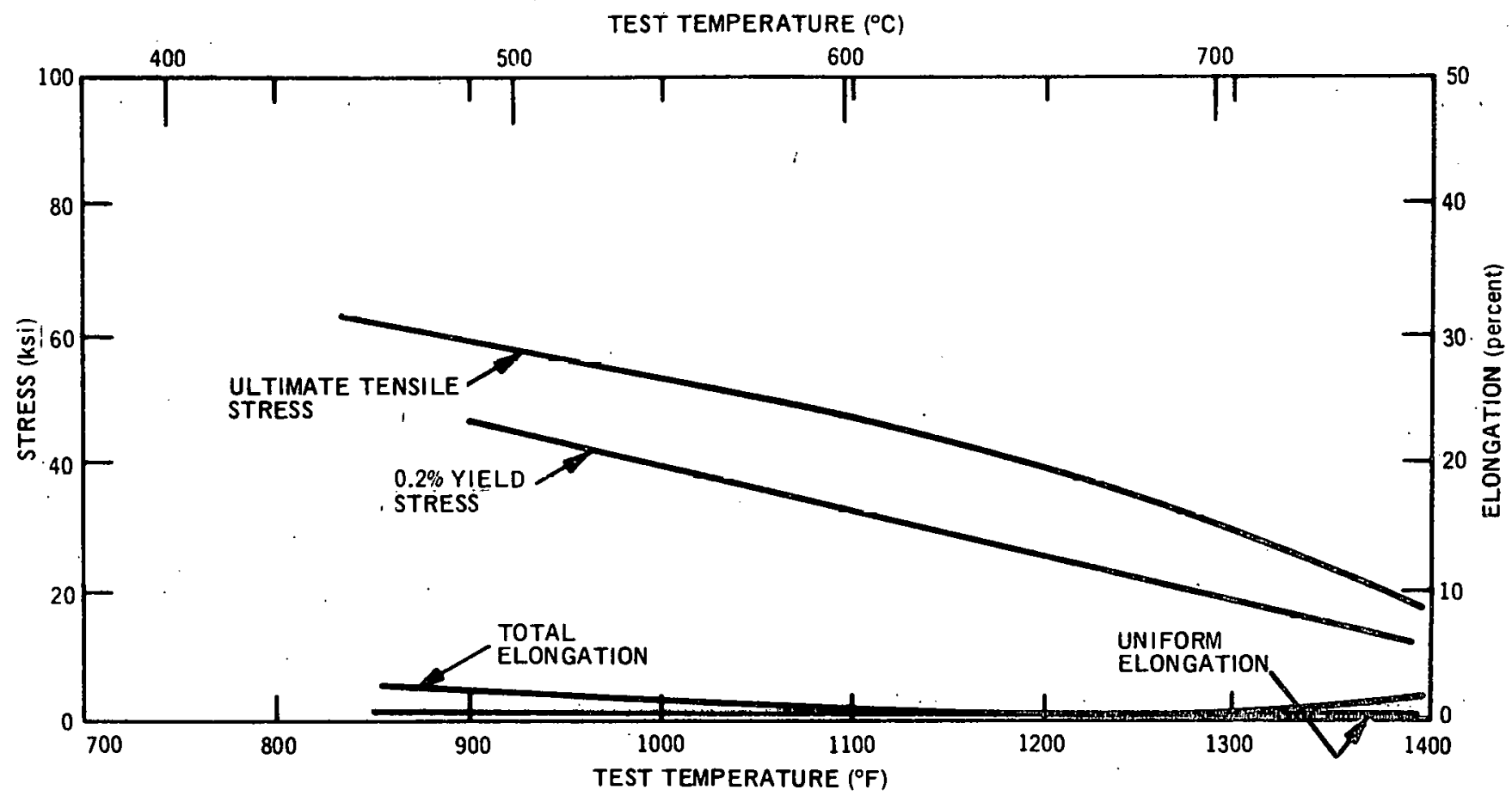

Figure 15. Recommended Tensile Properties Above Total Fluences of $10^{22}$ nvt as A Function of Test Temperature - Type-304 and -316 Stainless Steel

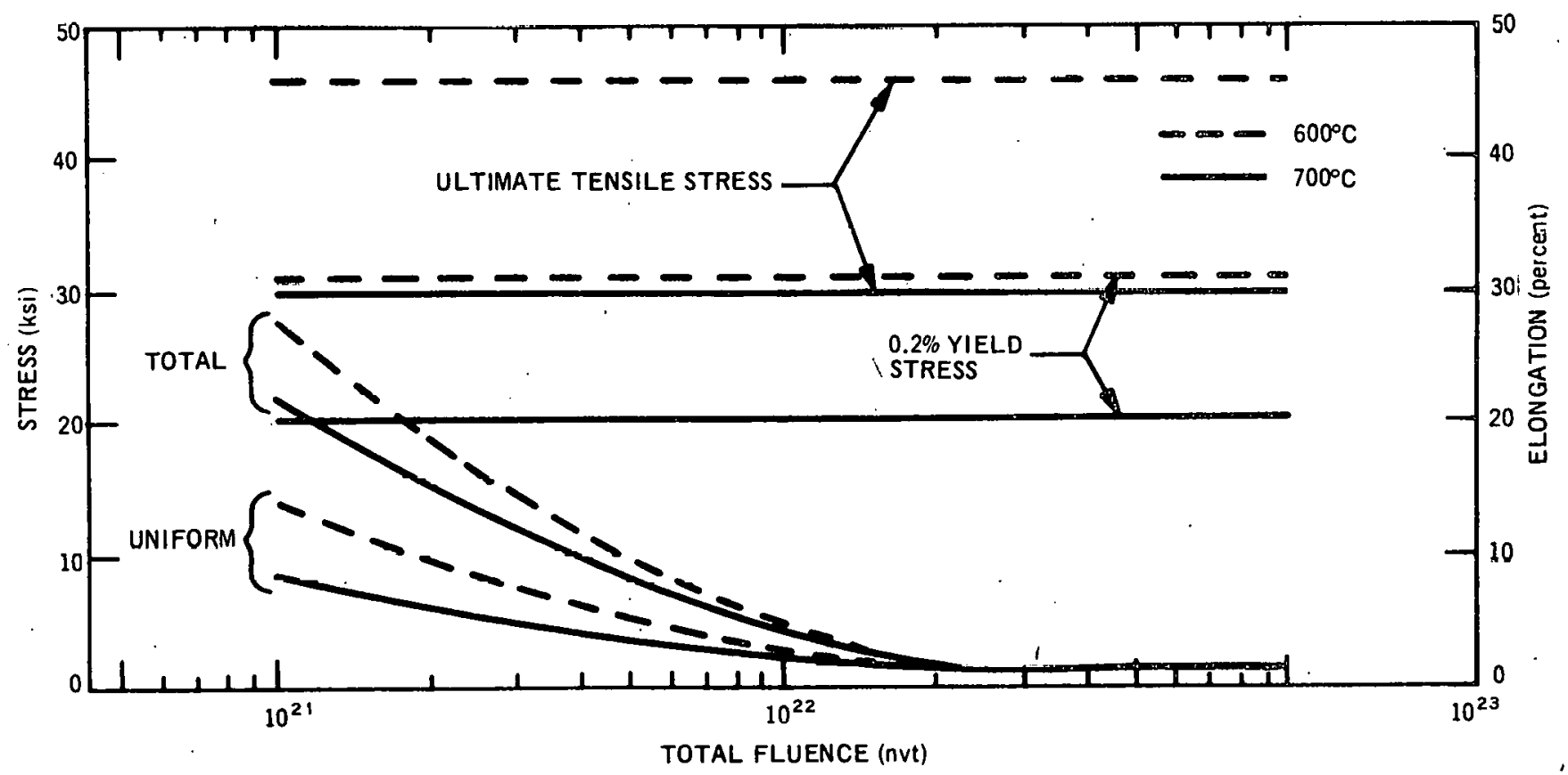

Figure 16. Recommended Tensile Properties as a Function of Total Fluence at $600^{\circ}$ and $700^{\circ} \mathrm{C}-$ Type- 304 and Type-316 Stainless Steel 


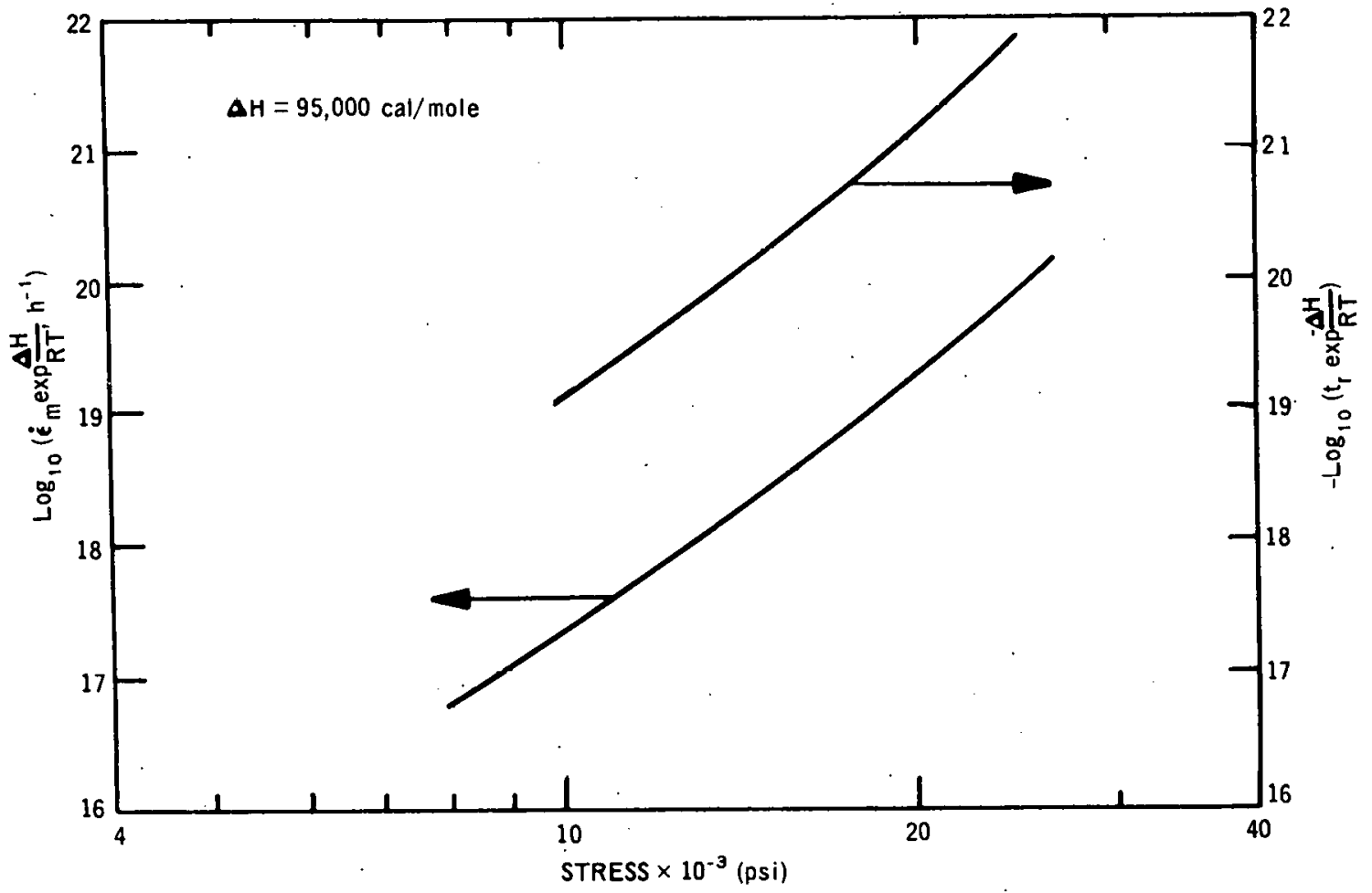

Figure 17. Parametric Design Curves for Minimum Creep Rate and Time-to-Rupture in Fast Reactor Environment at Fluences Above $10^{22}$ nyt, Type-304 and Type-316 Stainless Steel 


\section{REFERENCES}

1. Holmes, J. J., et al., Elevated Temperature Irradiation Hardening in Austenitic Stainless Steel, Acta Metallurgical, 16, 1968.

2. Holmes, J. J., Tensile Properties of 25 Percent ColdWorked and Annealed Austenitic Stainless Steels After Fasst Reactor Irradiation, Trans. ANS 11, No. 2, 1968.

3. Claudson, T. T., Editor, Quarterly Progress Report, Irradiation Effects on Reactor Structural Materials, May-July 1968, BNWL-870, September 1968, pg. 3.2.

4. Sodium-Cooled Reactors, Fast Ceramic Reactor Development Program, Twenty-Sixth Quarterly Report, February-April 1968, GEAP-5631, June 1968 , pg. 88.

5. Conner, J. G., and Porembka, S. W., Editors, A Compendium of Properties and Characteristics for Selected LMFBR Cladding Materials, BMI-1900, May 15, 1968, pg. II-35.

6. Robbins, R. E., Quarterly Progress Report, JulySeptember 1968, Reactor Fuels and Materials Development Programs for Fuels and Materials Branch of USAEC Division of Reactor Development and Technology, BNWL-919, November 1968, pg. 12.41.

7. Bagley, K. Q., et al., The Effects of Irradiation in DFR and DMTR on Austenitic Stainless Steels Proposed as PFR Cladding Materials. UKAEA Report TRG 1076 (D), August 1966.

8. Bagley, K. Q., and Fraser, A. S., Irradiation Effects on P.F.R. Cladding Materials Irradiated in the DFR and the DMTR, UKAEA Report TRG 791 (D), August 1964.
9. Murphy, W. F., and Strohm, H. E., Tube Burst Tests on Irradiated EBR-II Type 304L Stainless Steel Fuel Cladding, Nuclear Applications, 4 April 1968.

10. Sodium Cooled Reactors, Fast Ceramic Reactor Development Program, Twenty Fifth Quarterly Report, November, 1967-January 1968, GEAP-5584, March 1968.

11. Gilbert, R., Pacific Northwest Laboratory, Personal Communication, June 1968.

12. Weisż, M., et al., Contribution to the Studies Concerning the High-Temperature Embrittlement of AISI 316 Austenitic Stainless Steels After Irradiation, 1968 Annual AS'IM Meeting, San Francisco, California, June 1968.

13. Lovel, A. J., and Dunagan, G. A., Quarterly Report, July-September 1968, Reactor Fuels and Materials Development Programs, BNWL-919, November 1968, pg. 12.43.

14. Standring, J., and Bell, I. P., UKAEA Culcheth Laboratory, Personal Communication, September 1967.

15. Standring; J., and Tickle, H., UKAEA-UK Research Newsletter on Structural Materials, UK, RN. SM. 1, pg. 20, May 1966.

16. Standring, J., et al., UKAEA-UK Research Newsletter on Structural Materials, UK, RN. SM. 2, pg. 13, January 1967.

17. Unpublished information from Pacific Northwest Laboratories, October 1967. 


\section{DISTRIBUTION LIST-PA 10}

Director, Contracts Division

U. S. Atomic Energy Commission

San Francisco Operations Office

2111 Bancroft Way

Berkeley, California 94704

Chief, California Patent Group

U. S. Atomic Energy Commission

San Francisco Operations Office

P. O. Box 808

Livermore, California 94551

Division of Reactor Development and Technology

U. S. Atomic Energy Commission

Washington, D. C. 20545

Attn: Asst. Director for Reactor Engineering

Division of Reactor Development and Technology

U. S. Atomic Energy Commission

Washington, D. C. 20545

Attn: M. J. Whitman

Asst. Director for Program Analysis

Division of Reactor Development and Technolngy

U. S. Atomic Energy Commission

Washington, D. C. 20545

Attn: A. Giambusso

Asst. Director for Project Mgmt

(Attn: R. Sweek, G. Wensch, J. Morabito)

Division of Reactor Development and Technology

U. S. Atomic Energy Commission

Washington, D. C. 20545

Attn: J. A. Lieberman

Asst. Director for Nuclear Safety

Division of Reactor Development and Technology

U. S: Atomic Energy Commission

Washington, D. C. 20545

Attn: J. A. Lieberman

Asst. Director for Nuclear Safety

Division of Reactor Development and Technology

U.S. Atomic Energy Commission

Washington, D. C. 20545

Attn: J. W. Crawford

Asst. Director for Plant Engineering

Division of Reactor Development and Technology

U.S. Atomic Energy Commission

Washington, D. C.. 20.54.5

Attn: R. H. Steel

Division of Naval Reactors
2 Division of Reactor Development and Technology

U.S. Atomic Energy Commission

Washington, D. C. 20545

Attn: E. E. Sinclair

Asst. Director for Reactor Tech.

(Attn: J. M. Simmons; I. Zartman)

1

RDT Site Office

U.S. Atomic Energy Commission

c/o General Electric Company

310 DeGuigne Drive

Sunnyvale, California

2 Attn: J. V. Levy

LMFBR Program Office

Argonne National Laboratory

9800 South Cass Avenue

Argonne, Illinois 60439

Attn: A. Amorosi, Director

LMFBR Program Office

Argonne National Laboratory

9800 South Cass Avenue

3

Argonne, Illinois 60439

Attn: L. R. Kelman

Atomics International

2

P.0. Box 309

Canoga Park, California 91304

Attn: S. Golan

1

Director

Liquid Metals Information Center

P. O. Box 309

Canoga Park, California 91305

1 The Babcock \& Wilcox Company

Atomic Energy Division

Lynchburg, Virginia 24501

Attn: M. W. Croft

Mr. L. W. Fromm, Manager

11000 MWe LMFBR Follow-On Study Project

Building 208

Argonne National Laboratory

9800 South Cass Avenue

Argonne, Illinois 60439

1

FFTF Project

P. O. Box 220

8 


\section{DISTRIBUTION LIST (Continued)}

Mr. C. A. Anderson, Project Mgr 1000 MWe LMFBR Follow-On Study

Westinghouse Electric Corporation

Advanced Reactors Division

Waltz Mill Site

P. O. Box 158

Madison, Pennsylvania 15663

W. P. Staker, Project Manager 1000 MWe LMFBR Follow-On Study

Combustion Engineering, Inc.

P. O. Box 500

Windsor, Connecticut 06095

RDT Senior Site Representative

Canoga Park Area Office

P. O. Box 2325

San Diego, California 92112

RDT Senior Site Representative

Canoga Park Area Office

P. 0. Box 591

Canoga Park, California 91305

RDT Senior Site Representative

U.S. Atomic Energy Commission

Argonne National Laburatiory

9800 South Cass Avenue

Argonne, Illinois 60439

\section{RDT Site Office}

U.S. Atomic Energy Commission

Atomir. Power Development Assoriates, Inc.

1911 First Street

Detruil, Michigan 48226

RDT Senior Site Representative

Oak Ridge National Laboratory

P. O. Box X

Oak Ridge, Tennessee 37830

The Rahrock \& Wilcox Company

Alumic Energy Division

Lynchburg, Virginia 24501

Attn: S. H. Esleeck

RO'T Senior Site Representative

U.S. Atomic Energy Commission

P. O. Box 550

Richland, Washington 99352
2 RDT Site Representative

U.S. Atomic Energy Commission

Post Office Box 2108

Idaho Falls, Idaho 83401

RDT Site Representative

U.S. Atomic Energy Commission

United Nuclear Corporation

2 Grasslands Road

Elmsford, New York 10523

Attn: M. Napack .

RDT Site Representative

U.S. Atomic Energy Commission

1 United Nuclear Corporation

Grasslands Road

- Elmsford, New York 10523

Attn: A Strasser

1 Argonne National Laboratory 9800 South Cass Avenue

Argonne, Illinois 60439

Attn: J. H. Kittel

1 Argonne National Laboratory

9800 South Cass Avenue

Argonne, Illinois 60439

Attn: R. C. Vogel

Pacific Nurthwest Laboratory

$1 \quad$ P. O. Box 999

Richland, Washington 99352

Attn: E. A. Eschbach

Pacific Northwest Laboratory

P.O. Box 999

$1 \quad$ Richland, Washington 99352

Attn: E. A. Evans

University of California

1 P. O. Box 808

Livermore, California 94.551

Attn: A. Rothman

I.ss Alamos Scientific Laboratory

1

1 P. 0. Box I663

Los Alamos, New Mexico 87544.

Attn: R. D. Baker 


\section{DISTRIBUTION LIST (Continued)}

Los Alamos Scientific Laboratory P. O. Box 1663

Los Alamos, New Mexico 87544

Attn: D. B. Hall

Los Alamos Scientific Laboratory P. O. Box 1663

Los Alamos, New Mexico 87544

Attn: J. C..Clifford

Scientific Laboratory

P. 0. Box 1663

Los Alamos, New Mexico 87544,

Attn: Reports Librarian

Westinghouse Electric Corporation Bettis Atomic Power Laboratory P. 0. Box 79

West Mifflin, Pennsylvania

Attn: E. J. Kreh

Oak Ridge National Laboratory

P. O. Box X

Oak Ridge, Tennessee 37830

Attn: J. E. Cunningham

Brookhaven National Laboratory

Upton, New York 11973

Attn: O. E. Dwyer

Battelle Mcmorial Institutc

Columbus Laboratories

505 King Avenue

Columbus, Ohio 43201

Attn: D. Keller

Atomics International

P. 0. Box 309

Canoga Park, California 91304

Attn: H. Pearlman

Atomics Intcrnational

P. 0. Box 309

Canoga Park, California 91304

Attn: FBR Project Manager

$$
\text { (R. J. Beeley) }
$$

Dow Chemical Company

Rock Flats Division

P. O. Box 888

Golden, Colorado 80401

Attn: R. D. Forest
1 Scientific Representative

U.S. Atomic Energy Commission

American Embassy

APO San Francisco 96503

1 U.S. AEC Scientific Representative

United States Embassy

Paris, France

APO New York 09777

1 Senior U.S. AEC Representative

U.S. Mission to the European Communities United States Embassy

Brussels, Belgium

1 Division of Technical Information Ext.

U.S. Atomic Energy Commission

P. O. Box 62

Oak Ridge, Tennessee 37831

Dr. John C. Woodhouse

1 Guest Lane

Wilmington, Delaware 19809

Power Reactor Development Corp.

1911 First Street

Detroit, Michigan 48226

Attn: W. J. McCarthy

Argonne National Laboratory

Inaho Division

P. O. Box 1096

Idaho Falls, Idaho 83401

Attn: F. W. Thalgott

Detroit Edison Company

1911 First Street

Detroit, Michigan 48226

Attn: A. S. Griswold

1

Atomic Power Development Associates

1911 First Street

Detroit, Michigan 48226

Attn: A. A. Shoudy

1 Combustion Engineering, Inc.

Prospect Hill Road

Windsor, Connecticut 06095

Attn: W. P. Chernock . 


\section{DISTRIBUTION LIST (Continued)}

The Babcock \& Wilcox Company Atomic Energy Division

Lynchburg, Virginia 24501

Attn: H. S. Barringer

General Atomic

P. O. Box 608

San Diego, California 92112

Attn: D. B. Coburn

The Babcock \& Wilcox Company

Alliance. Research Center

Alliance, Ohio 44601

Attn: D. Koch

Westinghousc Elcctric Corporation

Advance Reactors Division

P. O. Box 217

Cheswick, Pennsylvania 15024

Attn: W. E. Ray

Nuclear Materials \& Equipment Corp.

Plutonium Laboratory

Leechburg, Pennsylvania 15656

Attn: William J. Ross
$1 \quad$ U. S. AEC Scientific Representative

United States Embassy

London, England

$1 \quad$ S. F. Stachura

Villa Plein Ciel

Quartier Roussier

Aix-en-Provence

13 - France

1

S. Visner

Nuclear Division

1

Combustion Engineering, Inc.

P. O. Box 500

Windsor, Connecticut 06095

W. B. Cottrell, Director

1 Nuclear Safety Program Oak Ridge National Laboratory P.O. Box Y

Oak Ridge, Tennessee 37830 